OPEN ACCESS

Edited by:

Bin Su,

Capital Medical University, China

Reviewed by:

Yi-Qun Kuang,

Kunming Medical University, China

Cong Jin,

Chinese Center For Disease Control

and Prevention, China

${ }^{*}$ Correspondence:

Zhengqin Gao

gaozhengqin@126.com

Yuxian $\mathrm{He}$

yhe@ipb.pumc.edu.cn

Specialty section: This article was submitted to Viral Immunology, a section of the journal

Frontiers in Immunology

Received: 29 April 2021 Accepted: 21 July 2021 Published: 10 August 2021

Citation:

Gao Z, Fu R, Li X, Wang J and He Y (2021) Safety Assessment of Microbicide 2P23 on the Rectal and Vaginal Microbiota and Its Antiviral Activity on HIV Infection.

Front. Immunol. 12:702172. doi: 10.3389/fimmu.2021.702172

\section{Safety Assessment of Microbicide 2P23 on the Rectal and Vaginal Microbiota and Its Antiviral Activity on HIV Infection}

\author{
Zhengqin $\mathrm{Gao}^{1,2 *}$, Rui $\mathrm{Fu}^{2}$, Xiaobo $\mathrm{Li}^{2}$, Ji Wang ${ }^{2}$ and Yuxian $\mathrm{He}^{1 *}$ \\ ${ }_{1}$ NHC Key Laboratory of Systems Biology of Pathogens, Institute of Pathogen Biology and Center for AIDS Research, \\ Chinese Academy of Medical Sciences and Peking Union Medical College, Beijing, China, ${ }^{2}$ Institute for Laboratory Animal \\ Resources, National Institutes for Food and Drug Control, Beijing, China
}

Containment of the AIDS pandemic requires reducing HIV transmission. HIV infection is initiated by the fusion of the membrane between the virus and the cell membrane of the host. 2P23 is an effective HIV membrane fusion inhibitor that may be a good entry inhibitor microbicide candidate. This study evaluated the potential of using gel-formulated 2P23 as a topical microbicide to prevent sexual transmission of HIV in the rectum and vagina. Our data revealed that 2P23 formulated in gel is effective against HIV. There was no change in antiviral activity at $25^{\circ} \mathrm{C}$ for 4 months or $60^{\circ} \mathrm{C}$ for 1 week. In addition, we demonstrated that the 2P23 gel was stable and fully functional at $\mathrm{pH}$ 4.0-8.0 and under different concentrations of $\mathrm{H}_{2} \mathrm{O}_{2}$. Finally, the $2 \mathrm{P} 23$ gel exhibited no cytotoxicity or antimicrobial activity and did not induce inflammatory changes in the rectal or vaginal mucosal epithelium in New Zealand rabbits after 20 mg/day daily rectovaginal application for 14 consecutive days. Despite repeated tissue sampling and 2P23 gel treatment, the inflammatory cytokines and microbiota of the rectum and vagina remained stable. These results add to general knowledge on the in vivo evaluation of anti-HIV microbicide application concerning inflammatory cytokines and microbiota changes in the rectum and vagina. These findings suggest that the $2 \mathrm{P} 23$ gel is an excellent candidate for further development as a safe and effective pre-exposure prophylactic microbicide for the prevention of HIV transmission.

Keywords: HIV, membrane fusion inhibitor, inflammatory cytokines, microbiota, mucosal immune system

\section{INTRODUCTION}

According to the latest global statistics report, 38 million individuals are living with HIV (1). Although 26 million patients received antiretroviral (ARV) treatment as of the end of June 2020, treatment efficacy is largely limited by daily medication, poor adherence, and the lifelong burden and stigma associated with side effects, such as kidney failure and bone loss $(2,3)$. It is well known that HIV transmission is primarily mediated via sexual contact. The rectal epithelium is composed 
of single-layered columnar cells and is a desired target for HIV viral penetration $(4,5)$. Preventing HIV transmission is of great importance, especially in individuals with a high risk of HIV exposure.

Modifying sexual behaviors and the use of condoms are fundamental prevention strategies for HIV transmission. Condoms are effective in preventing the transmission of HIV (6-8). However, consistent condom use is not optimal, and controls are lax. In addition, among the Ontario cohort of men who had sex with men (MSM), 693 were infected with HIV, and $51 \%$ (95\% confidence interval, 17\%-77\%) used condoms. These data indicate that despite the efficacy of condoms, condom failure occurs in gay men exposed to HIV (9).

In addition to condoms, microbicides are also applied for HIV prevention. To facilitate application to the rectum and vagina, microbicides are usually used in the form of lubricants, creams, gels, films, capsules, sponges, rings, tablets, electrospun fibers, suppositories, lavage, or enemas to topically prevent HIV from entering and/or replicating in mucosal cells (10-12). Topical pre-exposure prophylaxis (PrEP) is a microbicide that inhibits viral infection at the mucosal level $(13,14)$. The antiviral activity of PrEP is dependent on the antiretroviral regimen. Therefore, accumulation of antiretroviral drugs might induce side effects and have to be stopped. As a consequence, the antiviral property of PrEP is abrogated (15-22).

To maintain a sustained preventive effect, we synthesized a 2P23 peptide from the C-terminal heptapeptide repeat region (CHR) of the HIV fusion protein gp41 (23). In this study, we further assessed the activity and safety of 2P23 for blocking HIV infection. Herein, we report that $2 \mathrm{P} 23$ is a novel membrane fusion inhibitory peptide with exceptional potency against HIV infection in gel formulation. We also performed safety evaluations, assessing its cytotoxicity and antibacterial potential in vitro, and analyzed the inflammatory response and microbiota changes in vivo. Collectively, our data demonstrate the potential of 2P23 membrane fusion inhibitors as new antiviral agents for the prevention of HIV infection.

\section{MATERIALS AND METHODS}

\section{Ethics Statement}

All animal experiments were conducted in accordance with the guidelines and protocols approved by the Ethics Committee for Animal Experimentation of the National Institute for Food and Drug Control (NIFDC; Beijing, China) [protocol No. 2019 (B) 010]. To ensure personnel safety and animal welfare, research on animals was performed in strict accordance with the highest scientific, humane, and ethical principles concerning experiments set out in the Guidelines for the Care and Use of Laboratory Animals.

\section{Peptide Synthesis}

Peptides were synthesized on rink amide 4-methylbenzhydrylamine (MBHA) resin using standard solid phase 9-fluororenyl methoxycarbonyl (FMOC) chemistry at SciLight Peptide Biological Technology Co., Ltd. (SciLight Peptide; Beijing, China) and analyzed by high-performance liquid chromatography (HPLC) and matrix-assisted laser desorption ionization time of flight mass spectrometry (MALDI-TOF MS) to determine that the purity of the peptide was $>95 \%$. The concentration of the peptide was measured by UV absorbance and theoretically calculated by the molar extinction coefficients of tryptophan and tyrosine residues.

\section{Therapeutically Active Compound}

2P23 is a novel short peptide (23 mer) fusion inhibitor with an $\mathrm{M}-\mathrm{T}$ hook structure, HIV-2 sequence and salt bridge formation residue, and a molecular weight of $3717.96 \mathrm{~g} / \mathrm{mol}$ (2P23 amino acid sequence: EMTWEEWEKKVEELEKKIEELLK). 2P23 is a highly stable helical peptide that binds highly to surrogate targets from HIV-1, HIV-2, and simian immunodeficiency virus (SIV) and is effective at inhibiting HIV-1 and HIV-2 replication (mean $\mathrm{IC}_{50}$ for HIV-1, $5.57 \mathrm{nM}$; mean $\mathrm{IC}_{50}$ for HIV-2, $15.38 \mathrm{nM}$ ) (23).

\section{Virus Source and Cell Culture}

The Global HIV-1 ENV Cloning Group was obtained from David Montefiori through the NIH AIDS Reagent Program (AIDS Research and Reference Reagent Program, NIH, USA), Division of AIDS, NIAID, NIH. TZM-bl indicator cells were obtained from Dr. John C. Kappes, Dr. Xiaoyun $\mathrm{Wu}$, and Tranzyme Inc (24-29), which stably express large amounts of CD4 and CCR5 with endogenous expression of CXCR4 and were maintained in complete growth medium composed of DMEM (HyClone $^{\mathrm{TM}}$, GE Healthcare, Utah, USA) supplemented with $10 \%$ heat-inactivated FBS (Gibco, Grand Island, NY, USA), 100 $\mathrm{IU} / \mathrm{ml}$ penicillin, and $100 \mu \mathrm{g} / \mathrm{ml}$ streptomycin (HyClone). HEK293T cells and the human T-cell line MT-4 were purchased from the American Type Culture Collection (ATCC; Manassas, USA). Peripheral blood mononuclear cells (PBMCs) from healthy individuals were separated by FicollPaque Plus (GE Healthcare, Waukesha, USA) with density gradient centrifugation and stimulated with $5 \mu \mathrm{g} / \mathrm{ml}$ PHA (Sigma-Aldrich, St. Louis, USA) for $72 \mathrm{~h}$.

\section{Inhibitory Activity of Membrane Fusion Inhibitory Peptide on HIV}

The HIV membrane fusion inhibition peptide sensitivity test was performed by polyethylenimine (PEI) transfection to produce env-specific pseudoviruses. Briefly, 293T cells were cotransfected with env-deficient pSG3 $\Delta$ env plasmid DNA and pcDNA3.1-env plasmid containing the full-length env gene derived from plasma virus. The supernatant was collected, aliquoted, and stored at $-80^{\circ} \mathrm{C}$ until use. The titers of these viruses were determined by infecting TZM-bl cells, and the relative luminescence unit (RLU) readings were recorded using a Veritas microplate luminometer. The cutoff value was threefold higher than that of the cell control well, and 50\% tissue culture infectious doses $\left(\mathrm{TCID}_{50}\right)$ of the virus were calculated using the Reed and Muench method (30). To determine the peptide inhibitor dose corresponding to the $50 \%$ inhibitory concentration (IC50) with a confidence interval of 95\%, a piecewise linear dose-response curve was constructed for each virus type. After establishing a dose-response curve, the IC50 dose was estimated using appropriate correction techniques using GraphPad Prism 
statistical software. Under the linear assumption, the standard error of IC50 can be estimated (31).

\section{Hydroxyethyl Cellulose}

Hydroxyethyl cellulose (HEC) (catalog\# 434973) was purchased from Sigma-Aldrich (St. Louis, MO, USA). The HEC gel is a "universal" gel that has shown sufficient stability in gel formulation, as previously described (32-34), and is safe and sufficiently inactive to be used in clinical studies of experimental microbicides. In our study, the 2P23 gel dosage formulation was prepared using the gel method, and HEC was selected as the gelling agent. Aqueous systems containing decreasing concentrations (\%) of HEC were prepared to evaluate HEC cytotoxicity in TZM-bl cells using the Cell Counting Kit-8 (CCK-8; Kumamoto Michio, Japan) according to the manufacturer's instructions.

Cytotoxicity was evaluated by calculating the cell viability $=\left(\mathrm{OD}_{450}\right.$ of cell-HEC group $-\mathrm{OD}_{450}$ of blank control group $) /\left(\mathrm{OD}_{450}\right.$ of HEC-free cell control group $-\mathrm{OD}_{450}$ of blank control group) $\times 100 \%$. The evaluation criteria were derived from the Biological evaluation of medical devices-Part 5: Test for in vitro cytotoxicity (GB/T 16886.5-2017/ISO 10993-5:2009, IDT) (35).

\section{Products}

The 2P23 peptide in powder form was provided by Scilight Peptide (Beijing, China). A solution of 2P23 peptide was prepared in PBS. 2P23 gels consist of 2P23 peptide solutions of different concentrations added to a formulation containing a gel (HEC), glycerin, and the preservative methyl 4-hydroxybenzoate, filtered through a $0.45-\mu \mathrm{m}$ microporous membrane. Formulation of the vehicle control gel was the same but without the active ingredient (2P23).

\section{Physicochemical Property Testing}

The primary physicochemical parameters commonly used to evaluate semisolids include viscosity, osmotic pressure, and $\mathrm{pH}$. The viscosity was determined using the CP41 spindle on a Wells/ Brookfield $^{\mathrm{TM}}$ cone plate Brookfield Model DVIII viscometer (Brookfield Eng. Lab., Inc., MA, USA). Data were collected using Rheocalc software (Brookfield Eng. Lab., Inc., MA, USA). To compare data from different samples, viscosity values obtained at $50 \mathrm{~s}-1$ were used in the analysis. The shear stress (dyne/cm2) was best fitted by the Bingham equation using Rheocalc software. $\mathrm{pH}$ was determined using a Mettler-Toledo SevenExcellence ${ }^{\mathrm{TM}}$ Multiparameter $\mathrm{pH}$ meter (Mettler) with a Mettler-Toledo InLab ${ }^{\circledR}$ Expert Pro-ISM (Mettler) probe calibrated using three points, $\mathrm{pH}$ 4.01, 6.86, and 9.18. Osmolality was determined using a SMC30D osmometer (TianJin TianHe Analytic Instrument Co., Ltd, Tianjin, China) calibrated using GBW(E) 198.5, 600.8, and 1000 $\mathrm{mOsmol} / \mathrm{kg}$ calibration standards (National Institute of Metrology, Beijing, China).

\section{Cytotoxicity Test of the 2 P23 Gel In Vitro}

The toxicity of the 2P23 gel against PBMCs, CEMss-CCR5, MT-4, and TZM-bl cells was determined using a CCK-8 assay. Cytotoxicity was evaluated by calculating the cell viability $=\left(\mathrm{OD}_{450}\right.$ of cell-2P23 gel group $-\mathrm{OD}_{450}$ of blank control group $) /\left(\mathrm{OD}_{450}\right.$ of $2 \mathrm{P} 23$ gel-free cell control group $-\mathrm{OD}_{450}$ of blank control group) $\times 100 \%$. The evaluation criteria were derived from the Biological evaluation of medical devices-Part 5: Test for in vitro cytotoxicity (GB/T 16886.5-2017/ISO 10993-5:2009, IDT) (35).

\section{Antibacterial Activity of the 2P23 Gel}

The antimicrobial activity of the 2P23 gel was determined according to the Clinical and Laboratory Standards Institute (CLSI) guidelines $(36,37)$. Microorganisms used in the antibacterial test were Escherichia coli ATCC 25922, Pseudomonas aeruginosa ATCC 27853, Enterococcus faecalis ATCC 29212, and Staphylococcus aureus ATCC 25923. Reference microbial strains were purchased from ATCC, and a panel of probiotics strains, including Lactobacillus rhamnosus, Lactobacillus acidophilus, Lactobacillus reuteri, Lactobacillus fermentium, Lactobacillus casei, Lactobacillus paracasei, Lactobacillus delbrueckii subsp. bulgaricus, Bifido bacterium lactis, Bifidobacterium breve, Bifidobacterium bifidum, and Bifidobacterium longum, were purchased from Shanghai Aurinda Health Food Co., Ltd. Broth microdilution minimum inhibitory concentration (MIC) testing was performed for the $2 \mathrm{P} 23$ gel according to CLSI M07 and CLSI M100 guidelines. The viability of the bacteria was determined by measuring the optical density (OD) absorbance at $450 \mathrm{~nm}$, as described above. MICs were measured for bactericidal activity. Walch ${ }^{\circledR}$ Instant Hand Sanitizer positive controls (Kills 99.9\% of germs) (Whealth Lohmann CENTRALIN GmbH, Germany) were included for each organism-2P23 gel combination.

\section{Effect of $\mathrm{pH}$ and $\mathrm{H}_{2} \mathrm{O}_{2}$ on the Stability and Antiviral Activity of the 2P23 Gel}

The effect of $\mathrm{pH}$ on the 2P23 gel was evaluated at $\mathrm{pH} 4.0,6.0$, and 8.0. Briefly, the antiviral activity of $2 \mathrm{P} 23$ gels incubated at $\mathrm{pH} 4.0$, 6.0 , or 8.0 in complete growth medium at $37^{\circ} \mathrm{C}$ for $48 \mathrm{~h}$ was determined by a single-round viral infection assay using luciferase reporter gene detection in the abovementioned TZM-bl cells. To test the oxidation of $\mathrm{H}_{2} \mathrm{O}_{2}$, the $2 \mathrm{P} 23$ gel was treated with $1.2 \mu \mathrm{M} \mathrm{H}_{2} \mathrm{O}_{2}$ and $5 \mu \mathrm{M} \mathrm{H}_{2} \mathrm{O}_{2}$ as previously described (38). The antiviral activity of the $2 \mathrm{P} 23$ gel in $\mathrm{H}_{2} \mathrm{O}_{2}$ was determined as described above.

\section{Accelerated Stability and Antiviral Activity of the $2 \mathrm{P} 23 \mathrm{Gel}$}

The accelerated stability and antiviral activity of the 2P23 gel under different temperature and time conditions were studied. In brief, the $2 \mathrm{P} 23$ gel was stored at $4^{\circ} \mathrm{C}, 25^{\circ} \mathrm{C}, 40^{\circ} \mathrm{C}$, and $60^{\circ} \mathrm{C}$ for 1 to 24 weeks at $75 \%$ relative humidity $(\mathrm{RH})$. Equal portions of the 2P23 gel were taken weekly, diluted in complete medium, and incubated at $37^{\circ} \mathrm{C}$ for $48 \mathrm{~h}$. The antiviral activity was determined as described above. In addition, the stability of the 2P23 gel was further analyzed by HPLC.

\section{HPLC Experiment}

2P23 in gel or PBS was analyzed by HPLC on an Ultimate3000 (Thermo) liquid chromatograph. A reversed-phase Ultra Aqueous C18 analysis column $(2.1 \mathrm{~mm} \times 100 \mathrm{~mm}, 5-\mu \mathrm{m}$ particle size $)$ and guard column $(2.1 \mathrm{~mm} \times 12.5 \mathrm{~mm}, 5 \mu \mathrm{m}$ particle size $)$ were purchased from Agilent. ChemStation software (Agilent) was used to calculate the peak area $(\mathrm{Pa})$, and the recovery rate of $2 \mathrm{P} 23$ was calculated as " $\mathrm{X}$ week PA sample/0 week PA sample $\times 100 \%$ ". 


\section{Safety Evaluation in Rabbit Model In Vivo}

Rabbits are an ideal animal model for assessing rectal and vaginal products, as described elsewhere $(39,40)$. A total of 48 specific pathogen-free (SPF) New Zealand White (NZW) rabbits were provided by the National Center for Rodent Laboratory Animal Resources (Beijing, China). The rabbits were 8 to 9 weeks old and weighed between 1.790 and $2.424 \mathrm{~kg}$. For the in vivo safety study, 48 rabbits (24 male rabbits and 24 female rabbits) were randomized into 12 groups (two male rabbits and two female rabbits per group). Rabbits were randomly assigned to 12 experimental groups: placebo control group rabbits receiving PBS only $(n=4)$, vehicle control group rabbits receiving empty gel $(n=4)$, SFT gel high-dose group rabbits receiving gel formulation containing $20 \mathrm{mg} / \mathrm{ml} \mathrm{SFT}(n=4)$, SFT gel lowdose group rabbits receiving gel formulation containing $4 \mathrm{mg} / \mathrm{ml}$ SFT $(n=4), 2 \mathrm{P} 23$ gel high-dose group rabbits receiving gel formulation containing $20 \mathrm{mg} / \mathrm{ml} \mathrm{2P} 23(n=4), 2 \mathrm{P} 23$ gel lowdose group rabbits receiving gel formulation containing $4 \mathrm{mg} / \mathrm{ml}$ 2P23 $(n=4)$, LP80 gel high-dose group rabbits receiving gel formulation containing $20 \mathrm{mg} / \mathrm{ml} \mathrm{LP80}(n=4)$, LP80 gel lowdose group rabbits receiving gel formulation containing $2 \mathrm{mg} / \mathrm{ml}$ LP80 ( $n=4)$, LP98 gel high-dose group rabbits receiving gel formulation containing $20 \mathrm{mg} / \mathrm{ml} \mathrm{LP98}(n=4)$, LP98 gel lowdose group rabbits receiving gel formulation containing $2 \mathrm{mg} / \mathrm{ml}$ LP98 $(n=4)$, nonionic surfactants irritation control group rabbits receiving $100 \mathrm{mg} / \mathrm{ml}$ Triton X-100 $(n=4)$, and anionic surfactants irritation group rabbits receiving $100 \mathrm{mg} / \mathrm{ml}$ SDS ( $n=$ 4) (Table 1). Rabbits were dosed intrarectally and intravaginally with active formulation (2P23, SFT, LP80, and LP98), irritation control (Triton X-100, SDS), vehicle control (gel), or placebo control (PBS) using $4.7 \mathrm{~mm}$ (14Fr) silicone-rubber catheters (Yangzhou Huayue Technology Development Co., LTD,
Yangzhou, China) connected to a 20\# lavage apparatus with a syringe without needle. Active formulation compound gel, irritation control, vehicle control, or placebo control were placed in the rectal tract approximately $9 \mathrm{~cm}$ away from the anus and in the vaginal canal against the cervix approximately 5 $\mathrm{cm}$ away from the cunnus to their respective groups daily for 14 consecutive days. Rectal lavage (RL) and cervical lavage (CVL) were collected by irrigating the rectal walls and cervix and the lateral vaginal walls with PBS before (baseline) and after $24 \mathrm{~h}$ of administration of each dose. On the 14th day, rabbits were euthanized, the rectum and vagina were excised, and the middle was cut open. After macroscopic observation, tissue was removed from the upper, middle, and lower segments of the vagina or rectum for histopathological examination. Grading was performed based on Eckstein et al. (39).

\section{Histopathological Analysis of Mucosal Tissues}

The rectal and vaginal tissues were fixed for $24 \mathrm{~h}$ and evaluated for histopathological changes in mucosal tissues following in vivo treatment with 2P23 gel. In each biological sample, the rectal or vaginal epithelium was assessed for lesions, inflammatory infiltrates, vascular congestion, and/or submucosal edema. The evaluation criteria were derived from the Biological evaluation of medical devices-Part 10: Tests for irritation and skin sensitization (GB/T16886.10-2017/ISO10993-10:2010, IDT) (40).

\section{Evaluation of Inflammatory Cytokines}

Soluble markers of inflammation in CVL and RL were quantified by enzyme-linked immunosorbent assay (ELISA) using 14 commercially available rabbit cytokine kits (Cloud-Clone Corp., Wuhan, China). IL-4, IL-5, IL-6, IL-8, IL-10, IL-17,

TABLE 1 | Animal characteristics in the 2P23 gel trial

\begin{tabular}{|c|c|c|c|c|c|c|c|c|}
\hline Group & ID & Gender & Initial weight & Final weight & ID & Gender & Initial weight & Final weight \\
\hline PBS & 1 & Male & $2.193 \mathrm{~kg}$ & $2.452 \mathrm{~kg}$ & 25 & Female & $2.242 \mathrm{~kg}$ & $2.419 \mathrm{~kg}$ \\
\hline PBS & 2 & Male & $2.127 \mathrm{~kg}$ & $2.382 \mathrm{~kg}$ & 26 & Female & $2.136 \mathrm{~kg}$ & $2.336 \mathrm{~kg}$ \\
\hline Gel & 3 & Male & $2.176 \mathrm{~kg}$ & $2.495 \mathrm{~kg}$ & 27 & Female & $2.141 \mathrm{~kg}$ & $2.424 \mathrm{~kg}$ \\
\hline Gel & 4 & Male & $1.922 \mathrm{~kg}$ & $2.162 \mathrm{~kg}$ & 28 & Female & $1.836 \mathrm{~kg}$ & $2.022 \mathrm{~kg}$ \\
\hline $2 \%$ SFT gel & 5 & Male & $1.990 \mathrm{~kg}$ & $2.420 \mathrm{~kg}$ & 29 & Female & $2.368 \mathrm{~kg}$ & $2.569 \mathrm{~kg}$ \\
\hline $2 \%$ SFT gel & 6 & Male & 1.922 kg & $2.262 \mathrm{~kg}$ & 30 & Female & $2.053 \mathrm{~kg}$ & $2.324 \mathrm{~kg}$ \\
\hline $0.4 \%$ SFT gel & 7 & Male & $2.020 \mathrm{~kg}$ & $2.330 \mathrm{~kg}$ & 31 & Female & 1.956 kg & $2.080 \mathrm{~kg}$ \\
\hline $0.4 \%$ SFT gel & 8 & Male & $1.941 \mathrm{~kg}$ & $2.145 \mathrm{~kg}$ & 32 & Female & $2.096 \mathrm{~kg}$ & $2.335 \mathrm{~kg}$ \\
\hline 2\% 2P23 gel & 9 & Male & $2.121 \mathrm{~kg}$ & $2.449 \mathrm{~kg}$ & 33 & Female & 2.032 kg & $2.325 \mathrm{~kg}$ \\
\hline 2\% 2P23 gel & 10 & Male & $2.100 \mathrm{~kg}$ & $2.358 \mathrm{~kg}$ & 34 & Female & $1.840 \mathrm{~kg}$ & $2.055 \mathrm{~kg}$ \\
\hline $0.4 \% 2 \mathrm{P} 23 \mathrm{gel}$ & 11 & Male & $2.145 \mathrm{~kg}$ & $2.475 \mathrm{~kg}$ & 35 & Female & $1.996 \mathrm{~kg}$ & $2.362 \mathrm{~kg}$ \\
\hline $0.4 \% 2 \mathrm{P} 23 \mathrm{gel}$ & 12 & Male & $2.116 \mathrm{~kg}$ & $2.356 \mathrm{~kg}$ & 36 & Female & $2.248 \mathrm{~kg}$ & $2.390 \mathrm{~kg}$ \\
\hline 2\% LP80 gel & 13 & Male & $2.120 \mathrm{~kg}$ & $2.367 \mathrm{~kg}$ & 37 & Female & $2.268 \mathrm{~kg}$ & $2.443 \mathrm{~kg}$ \\
\hline 2\% LP80 gel & 14 & Male & $2.424 \mathrm{~kg}$ & $2.596 \mathrm{~kg}$ & 38 & Female & $2.291 \mathrm{~kg}$ & $2.338 \mathrm{~kg}$ \\
\hline $0.2 \%$ LP80 gel & 15 & Male & $2.205 \mathrm{~kg}$ & $2.522 \mathrm{~kg}$ & 39 & Female & $2.283 \mathrm{~kg}$ & $2.462 \mathrm{~kg}$ \\
\hline $0.2 \%$ LP80 gel & 16 & Male & $2.067 \mathrm{~kg}$ & $2.273 \mathrm{~kg}$ & 40 & Female & $2.427 \mathrm{~kg}$ & $2.542 \mathrm{~kg}$ \\
\hline 2\% LP98 gel & 17 & Male & $2.095 \mathrm{~kg}$ & $2.400 \mathrm{~kg}$ & 41 & Female & $2.248 \mathrm{~kg}$ & $2.434 \mathrm{~kg}$ \\
\hline 2\% LP98 gel & 18 & Male & $2.249 \mathrm{~kg}$ & $2.415 \mathrm{~kg}$ & 42 & Female & $2.070 \mathrm{~kg}$ & $2.240 \mathrm{~kg}$ \\
\hline $0.2 \%$ LP98 gel & 19 & Male & $2.170 \mathrm{~kg}$ & $2.384 \mathrm{~kg}$ & 43 & Female & $2.363 \mathrm{~kg}$ & $2.482 \mathrm{~kg}$ \\
\hline 0.2\% LP98 gel & 20 & Male & $2.090 \mathrm{~kg}$ & $2.292 \mathrm{~kg}$ & 44 & Female & $2.348 \mathrm{~kg}$ & $2.452 \mathrm{~kg}$ \\
\hline $10 \%$ Triton X-100 & 21 & Male & $2.109 \mathrm{~kg}$ & $2.420 \mathrm{~kg}$ & 45 & Female & $2.299 \mathrm{~kg}$ & $2.465 \mathrm{~kg}$ \\
\hline $10 \%$ Triton $X-100$ & 22 & Male & $1.823 \mathrm{~kg}$ & $2.126 \mathrm{~kg}$ & 46 & Female & $2.276 \mathrm{~kg}$ & $2.405 \mathrm{~kg}$ \\
\hline $10 \%$ SDS & 23 & Male & $1.790 \mathrm{~kg}$ & $2.116 \mathrm{~kg}$ & 47 & Female & $2.109 \mathrm{~kg}$ & $2.217 \mathrm{~kg}$ \\
\hline $10 \%$ SDS & 24 & Male & $1.956 \mathrm{~kg}$ & $2.226 \mathrm{~kg}$ & 48 & Female & $2.246 \mathrm{~kg}$ & $2.419 \mathrm{~kg}$ \\
\hline
\end{tabular}


IFN- $\gamma$, MCP-1, IL-1a, IL-1Ra, ELAM-1, ICAM-1, VEGFA, and PDGFA were included in these 14 cytokines that we tested. A standard curve was generated for each cytokine. The optical density was read using an Infinite ${ }^{\circledR}$ F50 absorbance microplate reader (Tecan). Cytokine concentration was calculated by quadratic regression analysis based on logarithmic transformation optical density.

\section{Rectal and Vaginal Microbiota Analysis Sample Collection}

RL and CVL samples were collected on September 10, 2019, and daily from September 17 to 30, 2019. To control for potential variants, RL and CVL samples were randomly chosen as follows (1): T0 (baseline): CM-01 (NWR1), CM-02 (NWR2), CF-01 (NWF1), and CF-02 (NWF2); (2) T14 (after 14 days administration): PBS group: PBSM1, PBSM2, PBSF25, and PBSF26; gel group: GELM3, GELM4, GELF27, and GELF28; SFT gel high-dose group: SFTHM5, SFTHM6, SFTHF29, and SFTHF30; SFT gel low-dose group: SFTLM7, SFTLM8, SFTLF31, and SFTLF32; $2 \mathrm{P} 23$ gel high-dose group: 2P23HM9, 2P23HM10, 2P23HF33, and 2P23HF34; $2 \mathrm{P} 23$ gel low-dose group: 2P23LM11, 2P23LM12, 2P23LF35, and 2P23LF36; LP80 gel high-dose group: LP80HM13, LP80HM14, LP80HF37, and LP80HF38; LP80 gel low-dose group: LP80LM15, LP80LM16, LP80LF39, and LP80LF40; LP98 gel high-dose group: LP98HM17, LP98HM18, LP98HF41, and LP98HF42; LP98 gel low-dose group: LP98LM19, LP98LM20, LP98LF43, and LP98LF44; Triton X-100 group: Triton100M21, Triton100M22, Triton100F45, and Triton100F46; SDS group: SDSM23, SDSM24, SDSF47, and SDSF48.

\section{DNA Extraction}

The total community genomic DNA of the RL and CVL samples was extracted using the E.Z. N. A Soil DNA Kit (Omega, USA) according to the manufacturer's instructions. The concentration of the DNA was determined using Qubit 2.0 (Life, USA).

\section{S rRNA Gene Amplification by PCR}

We targeted the V3-V4 hypervariable region of the bacterial $16 \mathrm{~S}$ rRNA gene. PCR was initiated immediately after DNA extraction. V3-V4 amplicons of the 16S rRNA gene were amplified using Kapa Hifi Hot Start Ready Mix $(2 \times)$ (Takara Bio Inc., Japan). Two common bacterial 16S rRNA gene amplification primers (purified by PAGE) were used: PCR forward primer 341F (5'-CCTACGGGNGGCWGCAC-3') and PCR reverse primer 805R (5'-GACTACHVGGGTATCT AATCC-3') (41).

\section{S Gene Library Construction, Quantification, and Sequencing}

The free primers and primer dimer species in the amplified products were purified using AmPure XP beads. Samples were sent to Shanghai Sangon Biotechnology Co., Ltd., China, for library construction using Universal Illumina adapters and indexes. Depending on coverage requirements, all the libraries can be pooled for one run. The amplified products in each reaction mixture were aggregated in equal molar ratios according to their concentration. Sequencing was performed using the Illumina MiSeq system (Illumina MiSeq, USA).

\section{Sequence Processing}

After sequencing, the data were collected as follows: (1) PEAR (V0.9.6) software was used to assemble two short Illumina readings based on the overlap and process FASTQ files to generate separate FASTA and QUAL files for analysis using standard methods; (2) sequences with ambiguous bases and lengths greater than 480 base pairs (bp) were removed, and the maximum allowable homopolymer length was 6 bp (42). Sequences shorter than 200 bp were removed; (3) all the same sequences were combined into one; (4) sequences were aligned according to the customized reference database; (5) the integrity of indexes and adapters was checked, and all indexes and adapter sequences were deleted; (6) noise was removed using PRE Cluster tools. Chimera UCHIME was used to detect Chimera. All software was in the mothur package. We resubmitted the valid sequences of each sample to the RDP classifier to identify archaea and bacterial sequences. Species richness and diversity statistics, including coverage, Chao1, Ace, Simpson, and Shannon-Ever, were calculated using mothur. The modified pipeline is described on the mothur website. Finally, all effective bacterial sequences without primers were submitted for data analysis (43).

\section{Sequencing Data Analysis}

Operational taxonomic units (OTUs) were established de novo using UCLUST, and 97\% sequence homology was truncated (44). OTUs for regions V3-V4 were specified by the Ribosomal Database Project (RDP) Naive Bayes classifier $(45,46)$. This sequence was compared to the Greengenes core set using the Python nearest alignment space termination (PyNAST) aligner (47). Phylogenetic trees were generated using FastTree, and dilution curves were drawn to calculate alpha and beta diversity of the samples performed by QIIME (48). Similarities between microbial communities were identified using principal coordinate analysis (PCoA), which relies on unweighted and weighted UniFrac. UCHIM software was used to detect and remove chimeric sequences based on the "RDP GOLD" database. OTU cluster analysis was performed according to the Galaxy online platform process. The BIOM file obtained by the QIIME software was uploaded to the Galaxy website for predictive analysis of the Phylogenetic Investigation of Communities by Reconstruction of Unobserved States (PICURSt) functional genes. The information could be obtained by referring to the Kyoto Encyclopedia of Genes and Genomes (KEGG) Orthology class 1 and class 2 functional gene classes to obtain the functional composition of the predicted genome (49).

\section{Statistical Analysis}

All data were derived from at least three separate experiments. All experimental data are expressed as the mean \pm standard deviation (Mean \pm SD). One-way ANOVA was used, followed by GraphPad Prism (Version 7.00, GraphPad Software, Inc., La Jolla, CA, USA) and Microsoft Excel [Office 365; Microsoft Corp. (MSFT)]. Statistical significance was defined as $p<0.05$. 


\section{RESULTS}

\section{Cytotoxicity of HEC In Vitro}

The toxicity of HEC against TZM-bl cells was measured using a CCK-8 assay kit. The survival of TZM-bl cells was assessed under different concentrations of HEC. The results are summarized in Table 2. The $0.1 \%$ HEC gel, $0.5 \%$ HEC gel, $1 \%$ HEC gel, $1.5 \%$ HEC gel, and 2\% HEC gel were level 1, and the cell viability was $99.7 \%, 97.5 \%, 93.4 \%, 89.4 \%$, and $83.5 \%$, respectively. The $5 \%$ HEC gel, 7\% HEC gel, 10\% HEC gel and 15\% HEC gel were level 2 , and their cell viability values were $79.3 \%, 73.53 \%, 65.1 \%$ and $60 \%$, respectively. No cytotoxicity (level 0 ) was defined as cell viability $\geq 100 \%$, minimum cytotoxicity (level 1) was defined as $80 \% \leq$ cell viability $<100 \%$, mild cytotoxicity (level 2 ) was defined as $50 \% \leq$ cell viability $<80 \%$, moderate cytotoxicity (level 3 ) was defined as $30 \% \leq$ cell viability $<50 \%$, and severe cytotoxicity (level 4) was defined as cell viability $<30 \%$. A grade greater than 2 using this method is considered cytotoxic. A decrease in cell viability greater than $30 \%$ is considered cytotoxic. Different concentrations of HEC gel $(0.1 \%, 0.5 \%, 1 \%, 1.5 \%, 2 \%, 5 \%, 7 \%, 10 \%$, and $15 \%$ HEC) were screened. According to the evaluation criterion in ISO10993 (35), the cytotoxicity of the $0.1 \%-2 \%$ HEC gel was of ranking 1 and qualified (Figure 1). Due to the fluidity and the difficulty of filtration, the $1.5 \%$ HEC gel was selected as the final concentration.

\section{P23 Gel Formulation Evaluation}

Formulation tests are required to predict the effect of the product when applied to mucosal surfaces. The primary physicochemical properties commonly assessed for semisolids include osmolality, viscosity, and $\mathrm{pH}$. Osmolality was measured to determine how the drug deviated from isosmolar $(290 \mathrm{mOsmol} / \mathrm{kg})$ conditions. This is important because hypertonic products can cause mucosal tissue damage. The osmolality values of the $2 \mathrm{P} 23$ gel and its vehicle control gel were 8.8 -fold $(2,540 \mathrm{mOsmol} / \mathrm{kg})$ and 7.8 -fold $(2,250 \mathrm{mOsmol} / \mathrm{kg})$, respectively, greater than those under isosmolar conditions. The $\mathrm{pH} 4.4$ or $\mathrm{pH} 7.4$ of both gels

TABLE 2 | Cytotoxicity of HEC on TZM-bl cells.

\begin{tabular}{lcc}
\hline Group $(\boldsymbol{n}=\mathbf{3})$ & Cell viability (mean $\mathbf{\pm S D})$ & Level $^{*}$ \\
\hline Cell control & 100 & 0 \\
$0.1 \%$ HEC-gel & $99.66 \pm 0.76$ & 1 \\
$0.5 \%$ HEC-gel & $97.49 \pm 0.20$ & 1 \\
$1.0 \%$ HEC-gel & $93.43 \pm 0.40$ & 1 \\
$1.5 \%$ HEC-gel & $89.43 \pm 0.23$ & 1 \\
$2.0 \%$ HEC-gel & $83.54 \pm 0.65$ & 1 \\
$5.0 \%$ HEC-gel & $79.28 \pm 0.42$ & 2 \\
$7.0 \%$ HEC-gel & $73.52 \pm 0.20$ & 2 \\
$10.0 \%$ HEC-gel & $65.13 \pm 0.51$ & 2 \\
$15.0 \%$ HEC-gel & $59.98 \pm 1.35$ & 2 \\
\hline
\end{tabular}

${ }^{*}$ Cytotoxicity evaluation: cell viability, no cytotoxicity (level 0) was defined as cell viability $\geq$ $100 \%$, minimum cytotoxicity (level 1) was defined as $80 \% \leq$ cell viability $<100 \%$, mild cytotoxicity (level 2) was defined as $50 \% \leq$ cell viability < $80 \%$, moderate cytotoxicity (level 3) was defined as $30 \% \leq$ cell viability $<50 \%$, and severe cytotoxicity (level 4) was defined as cell viability $<30 \%$. A grade greater than 2 by this method is considered cytotoxic. $A$ decrease in cell viability greater than $30 \%$ is considered cytotoxic. The evaluation criteria were derived from the Biological evaluation of medical devices - part 5: test for in vitro cytotoxicity (GB/T 16886.5-2017/ISO 10993-5:2009, IDT).

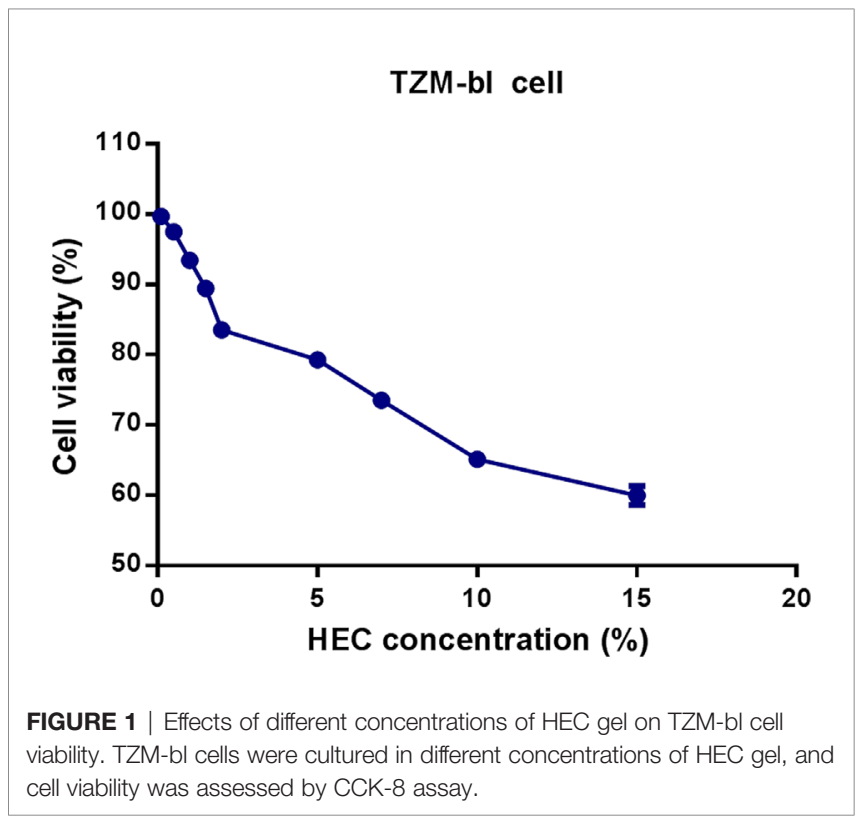

was similar to that of the vaginal and rectal environment. The viscosities of the 2P23 gel and its vehicle control gel were 1543 centipoise (cps) and $1316 \mathrm{cps}$, respectively, at a shear rate of 3 $\mathrm{rpm}$. These results were reproducible in repeated trials.

\section{The 2P23 Gel Exhibits No Cytotoxicity In Vitro}

To determine whether the 2P23 gel exerts cytotoxicity in vitro, we incubated PBMCs, CEMss-CCR5, MT-4, and TZM-bl cells with the $2 \mathrm{P} 23$ gel at graded concentrations and assessed their cell viability by CCK-8 assay. As illustrated in Figure 2, the 2P23 gel exhibited no in vitro cytotoxicity to PBMCs, CEMss-CCR5, MT4 , or TZM-bl cells at concentrations as high as $6270 \mathrm{nM}$, which is approximately 1,126-fold higher than the $\mathrm{IC}_{50}$ of $2 \mathrm{P} 23$ for inhibiting HIV-1 infection, suggesting that the $2 \mathrm{P} 23$ gel has a good safety profile.

\section{The 2P23 Gel Efficiently Inhibits HIV Infections In Vitro}

We therefore formulated 2P23 peptide in gel or in PBS. In our study, 2P23 showed strong broad-spectrum inhibitory activity against HIV-1, such as pseudotyped HIV-1 CRF01_AE (CNE55), B (X2278_C2_B6), C (HIV_25710-2.43), and G (X1632_S2_B10), with the mean $\mathrm{IC}_{50}$ values range of 0.5908 $2.084 \mathrm{nM}$ (Figure 3). To enhance the translational potential of human vaginal and rectal applications, the $2 \mathrm{P} 23$ peptide was reformulated in gel rather than PBS to achieve equivalent potency in vitro. The $2 \mathrm{P} 23$ gel demonstrated full activity against HIV-1, confirming the effective delivery of the $2 \mathrm{P} 23$ peptide in the gel formulation.

\section{The 2 P23 Gel Lacks Antibacterial Activity In Vitro}

Lactobacillus, Bifidobacterium, Enterobacter, and Enterococcus are found in a healthy vagina or rectum. They are essential for 

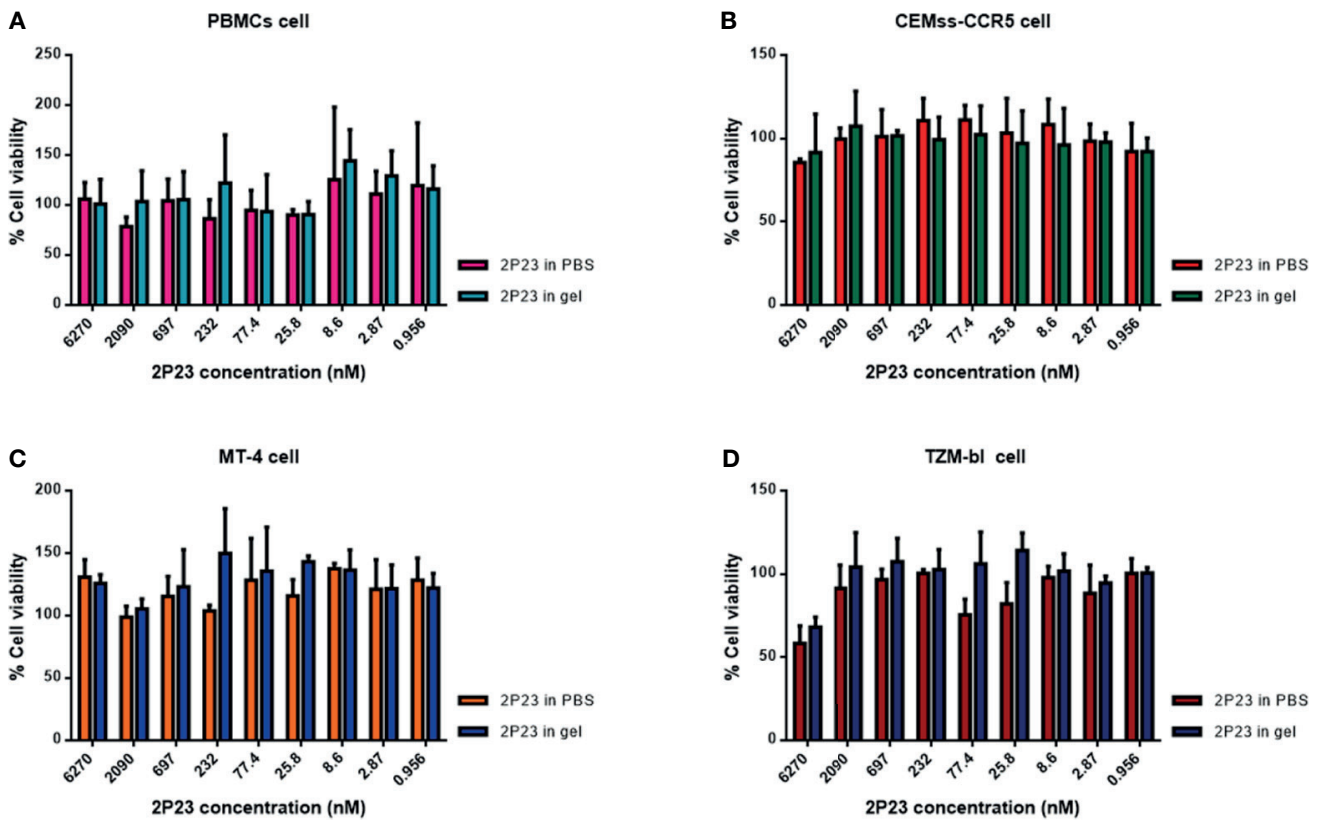

FIGURE 2 | In vitro cytotoxicity of the 2P23 gel. The viability of PBMCs (A), CEMss-CCR5 (B), MT-4 (C), and TZM-bl (D) cells treated with 2P23 formulated in ge or in PBS at graded concentrations was evaluated by CCK-8 assay.

maintaining an acidic environment ( $\mathrm{pH} 3.5-4.5)$ or a neutral environment ( $\mathrm{pH} 7.4-8.4$ ) and produce a variety of antiviral and antibacterial substances that inhibit pathogens. Alterations in the normal rectovaginal microbiota can lead to multiple rectovaginal infections and affect the risk of rectovaginal HIV transmission. Therefore, the 2P23 gel must not interfere with normal rectovaginal microbiota. The effects of the 2 P23 gel on rectovaginal bacteria were studied using 15 different species of bacteria, namely, E. coli, $P$. aeruginosa, E. faecalis, S. aureus, $L$. rhamnosus, $L$. acidophilus, $L$. reuteri, L. fermentium, $L$. casei, $L$. paracasei, L. delbrueckii subsp. bulgaricus, B. lactis, B. breve, $B$. bifidum, and $B$. longum, and $2 \mathrm{P} 23$ gels did not affect the growth of the bacteria to $2,689,500 \mathrm{nM}$ concentrations $(\approx 482,855$-fold higher than the $\mathrm{IC}_{50}$ ) (Table 3). These studies indicate that 2P23 gels do not affect the normal rectovaginal microbiota.

\section{Antiviral Activity of the 2P23 Gel Is Preserved at Different $\mathrm{pH}$ and $\mathrm{H}_{2} \mathrm{O}_{2}$ Conditions}

The $2 \mathrm{P} 23$ gel is used in the vagina or rectum and therefore must be stable in the acidic $\mathrm{pH}$ of a healthy vagina ( $\mathrm{pH} 3.5$ to 4.5 ), near-neutral $\mathrm{pH}$ after ejaculation, or a healthy rectum ( $\mathrm{pH} 7.4$ to 8.4). The $2 \mathrm{P} 23$ gel should not be oxidized by $\mathrm{H}_{2} \mathrm{O}_{2}$ in the vaginal cavity. Under different $\mathrm{pH}$ and $\mathrm{H}_{2} \mathrm{O}_{2}$ conditions (Figure 4), the 2P23 gel always inhibited viral replication efficiently, indicating that $\mathrm{pH}$ and $\mathrm{H}_{2} \mathrm{O}_{2}$ had no significant effect on its antiviral activity. In conclusion, the high stability of the $2 \mathrm{P} 23$ gel under different $\mathrm{pH}$ and $\mathrm{H}_{2} \mathrm{O}_{2}$ conditions indicates that it is an ideal vaginal and rectal microbicide.

\section{P23 Formulated in Gel Is Stable at Different Temperatures}

The 2P23 peptide must remain stable at different temperatures during the shelf life of the compound and in the human body during the manufacture of microbicides. To test their thermal stability, $2 \mathrm{P} 23$ gels were stored at $60^{\circ} \mathrm{C}$ for 1 week, $40^{\circ} \mathrm{C}$ for 8 weeks, $25^{\circ} \mathrm{C}$ for 16 weeks, and $4^{\circ} \mathrm{C}$ for 24 weeks. Antiviral activity was measured and compared to the control measured at $37^{\circ} \mathrm{C}$ for $48 \mathrm{~h}$ (Figure 5). The $2 \mathrm{P} 23$ gel showed the same antiviral activity when stored at $60^{\circ} \mathrm{C}$ for 1 week, $40^{\circ} \mathrm{C}$ for 8 weeks, $25^{\circ} \mathrm{C}$ for 16 weeks, and $4^{\circ} \mathrm{C}$ for 24 weeks. Together, these results highlight the very high thermal stability of the $2 \mathrm{P} 23$ gel. As shown in Figure 6, compared to the freshly prepared gel ( 0 weeks), $2 \mathrm{P} 23$ in the gel stored at $40^{\circ} \mathrm{C}$ for 8 weeks and $2 \mathrm{P} 23$ in PBS had the same peak shape and preservation time. At the end of the 8 th week of storage at $40^{\circ} \mathrm{C}$, the recoveries of $2 \mathrm{P} 23$ in gel and PBS were both $100 \%$, indicating that there were no obvious drug loss or degradation products after a sufficient period of storage at relatively high temperature.

\section{The 2P23 Gel Does Not Significantly Irritate or Damage the Rectal or Vaginal Mucosa}

The study was designed to have four animals per experimental group. Lifestyle observation involves assessing signs of irritation in the rectal and vaginal areas. After 14 days of rectal or vaginal administration of the 2P23 gel, no 2P23 gel-related changes with respect to physical signs or body weight were observed in animals. No significant abnormalities were found in the body 
A

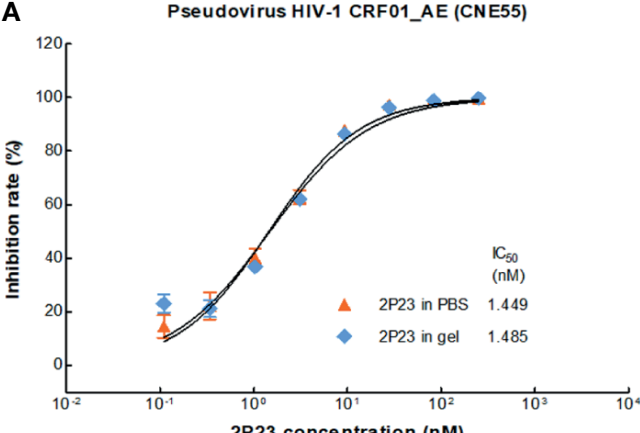

C

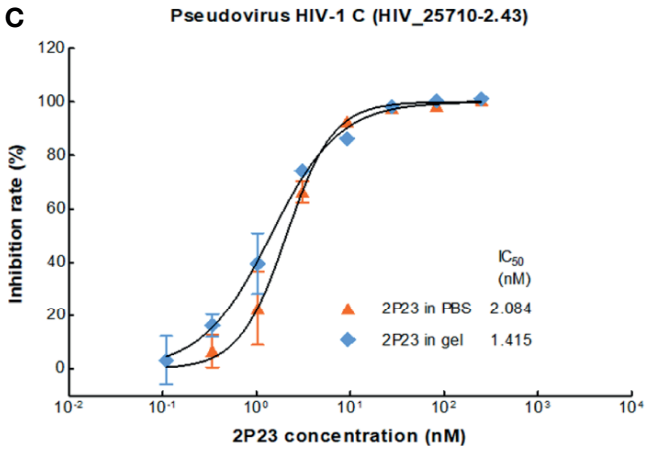

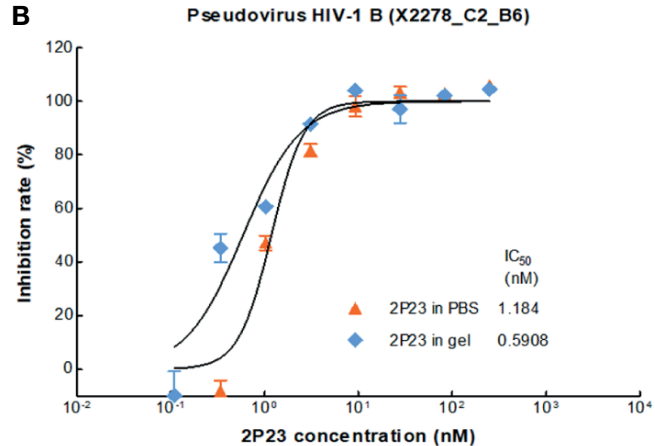

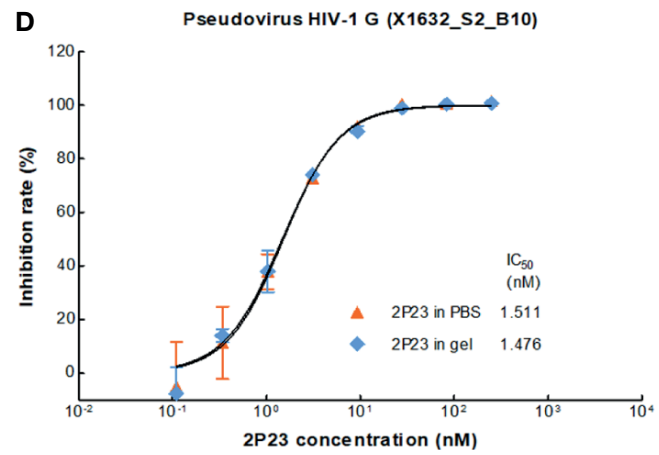

FIGURE 3 | Antiviral activity of the $2 \mathrm{P} 23$ gel. $2 \mathrm{P} 23$ formulated in gel or in PBS was incubated at $37^{\circ} \mathrm{C}$ for $48 \mathrm{~h}$ The antiviral activity of $2 \mathrm{P} 23$ in gel or in PBS was evaluated using a single-round viral infectivity assay using TZM-bl reporter cells and HIV-1 (A) pseudotyped HIV-1 CRF01_AE (CNE55), (B) pseudotyped HIV-1 B (X2278_C2_B6), (C) pseudotyped HIV-1 C (HIV_25710-2.43), and (D) pseudotyped HIV-1 G (X1632_S2_B10). The experiments were performed with an initial concentration of 2P23 peptide at $250 \mathrm{nM}$. These assays were performed in triplicate and repeated three times. Percent inhibition of 2P23 in gel or in PBS and IC 50 values were calculated as described in the text. Data were expressed as means \pm standard deviations (SD).

TABLE 3 | In vitro anti-bacterial activity of 2P23 gel on Lactobacillus, Bifidobacterium, Enterobacter, and Enterococcus species.

\section{Bacteria strain}

Escherichia coli ATCC 25922

Pseudomonas aeruginosa ATCC 27853

Enterococcus faecalis ATCC 29212

Staphylococcus aureus ATCC 25923

Lactobacillus rhamnosus

Lactobacillus acidophilus

Lactobacillus reuteri

Lactobacillus fermentium

Lactobacillus casei

Lactobacillus paracasei

Lactobacillus delbrueckii subsp. bulgaricus

Bifidobacterium lactis

Bifidobacterium breve

Bifidobacterium bifidum

Bifidobacterium longum

${ }^{*} M I C$, minimal inhibitory concentration.

$2 P 23$ gel MIC at 2,689,500 nM, which is $\approx 482,855$-fold higher than the $/ C_{50}$.

surface, anus, or vagina by gross examination. Histopathological examination of the rectum and vagina is shown in Figure 7. No significant irritation was observed in the high or low doses of the 2P23 gel compared to the control group. At autopsy, rectal and vaginal irritation was assessed by the Eckstein method, which reflects the collective histopathological grading of four parameters within the vagina, including epithelial morphology, leucocyte infiltration, congestion, and edema. A mean irritation score of $\leq 8$ was considered acceptable for clinical testing of rectal and vaginal products. The results of the rabbit model showed good safety profiles for the $2 \% 2 \mathrm{P} 23$ gel and $0.4 \% 2 \mathrm{P} 23$ gel. No gross anatomic pathology associated with $2 \mathrm{P} 23$ gel treatment was observed at any dose. There were few to no rectal or vaginal lesions on the 2P23 gel following once-daily dosing for 14 days. There was virtually no detectable rectal or vaginal irritation during the study. In the postmortem individual Eckstein score (maximum score 16) for the rectum and vagina of male and female rabbits at $4 \mathrm{mg}$ /day, the $20 \mathrm{mg}$ /day dose group was generally comparable between the two groups and ranged from none to minimal magnitude (ranging from 1 to 4 in the rectum and vagina). In rabbits treated with $100 \mathrm{mg} /$ day SDS, epithelial disruption and vascular congestion were observed. Some tissues exhibited necrotic ulcerative granuloma. The inflammatory infiltrate had spread to the submucosa and may be severe. The histopathologic mean irritation scores are illustrated in Table 4. The total score obtained in these rabbit samples indicated the presence of average rectal and vaginal irritation. Taken together, these results suggest that $2 \mathrm{P} 23$ can be safely used as a microbicide 

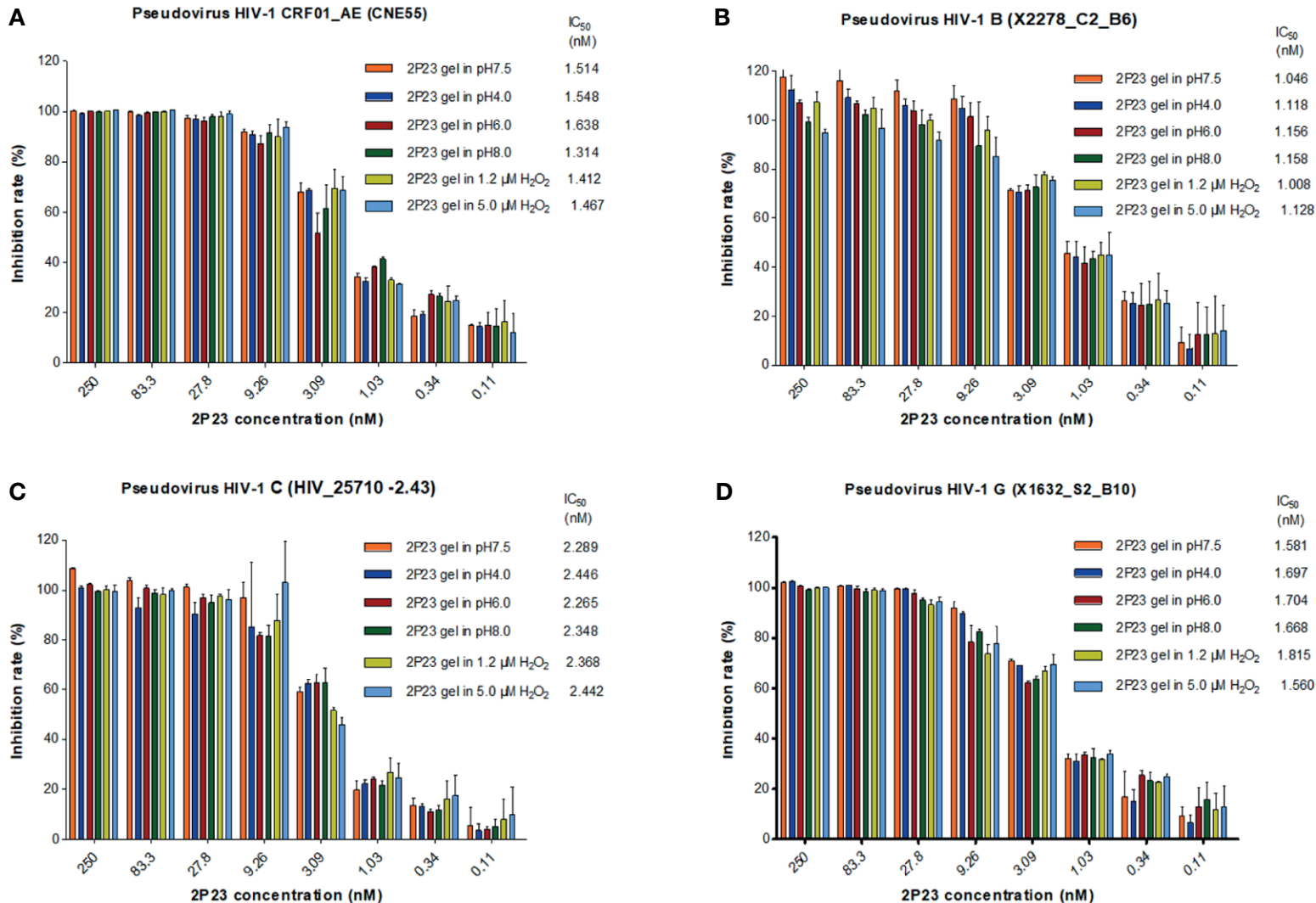

FIGURE 4 | Antiviral activity of the 2P23 gel under different $\mathrm{pH}$ and $\mathrm{H}_{2} \mathrm{O}_{2}$ conditions. A 2P23 gel was prepared in complete growth medium (GM) at pH 7.5, 4.0, 6.0, and 8.0 or in the presence of $1.2 \mu \mathrm{M} \mathrm{H}_{2} \mathrm{O}_{2}$ and $5 \mu \mathrm{M} \mathrm{H}_{2} \mathrm{O}_{2}$ and incubated at $37^{\circ} \mathrm{C}$ for $48 \mathrm{~h}$ Single-round viral infection tests were performed using TZM-bl reporter cells and HIV-1 (A) pseudotyped HIV-1 CRF01_AE (CNE55), (B) pseudotyped HIV-1 B (X2278_C2_B6), (C) pseudotyped HIV-1 C (HIV_25710-2.43), and (D) pseudotyped HIV-1 G (X1632_S2_B10). The experiments were performed with an initial concentration of $2 \mathrm{P} 23$ peptide at $250 \mathrm{nM}$. These assays were performed

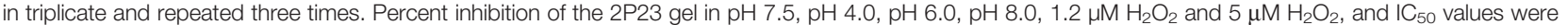
calculated as described in the text. Data are expressed as means \pm standard deviations (SD).

at doses up to $20 \mathrm{mg} /$ day $(5,379,000 \mathrm{nM})$. After 14 days of continuous rectal and vaginal administration of the $2 \mathrm{P} 23$ gel, no 2P23 gel-related changes in physical signs or body weight were observed in rabbits. Histopathological examination found no irritation of the $2 \mathrm{P} 23$ gel to the rectal or vaginal mucosa, indicating that the product has good safety.

\section{The 2P23 Gel Does Not Significantly Trigger Rectal or Vaginal Mucosa Secretion of Inflammatory Cytokines}

To further evaluate the inflammatory potential of the 2P23 gel on the rectal and vaginal mucosa, RL and CVL were collected from each test animal after 14 consecutive days of treatment, and the presence of 14 cytokines was measured and quantified by ELISA. We measured the secretion of inflammatory cytokines triggered by these candidate microbicides at local sites of the mucosa. Compared to PBS, the 2P23 gel did not induce obvious enhancement of cytokine production (Table 5). Taken together, the HIV membrane fusion inhibitor 2P23 gel has the potential to be developed as a safe and effective
anti-HIV microbicide for the prevention of sexual transmission of HIV.

\section{The 2 P23 Gel Is Not Associated With Changes to the Rectal or Vaginal Microbiota}

Maintenance of the mucosal barrier is critical for preventing microbial invasion, including HIV, and bacterial diversity in the rectum and vagina is closely associated with mucosal inflammation, which negatively affects local vulnerability to HIV infection. Microbial communities in the rectum and vaginal mucosal sites may influence the efficacy of topical HIV drugs $(50,51)$. We evaluated changes in the composition of the microbiota in vaginal and rectal samples before and after 2P23 gel administration using bacterial 16S rRNA sequencing. We collected pairs of RL and CVL samples from $48 \mathrm{NZW}$ rabbits and simultaneously treated the extracted DNA and sequenced $16 \mathrm{~S}$ ribosomal RNA genes, providing a strong opportunity for comparative evaluation of these different mucosal compartments. In addition, the mean sequencing depth 
A

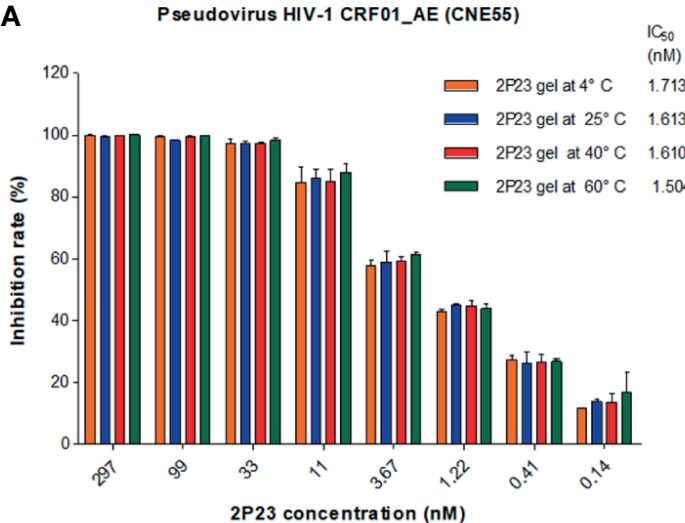

C

Pse udovinus HIV-1 C (HIV_25710-2.43)

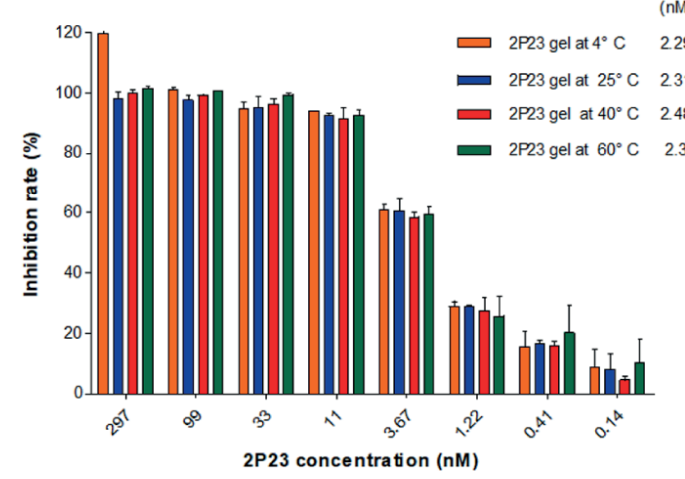

B
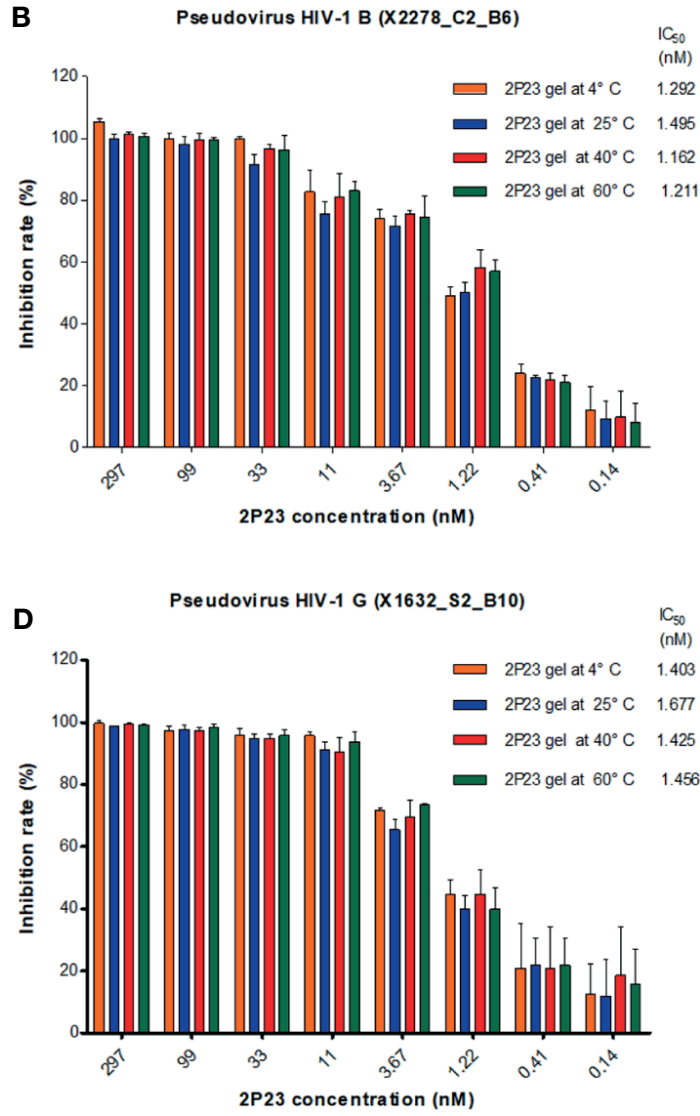

FIGURE 5 | Antiviral activity and biological stability of the 2P23 gel at different temperature conditions. Stability of the 2P23 gel in complete growth medium was evaluated in a biological assay as a function of temperature. Thermal degradation studies were conducted at $60^{\circ} \mathrm{C}$ for 1 week, $40^{\circ} \mathrm{C}$ for 8 weeks, $25^{\circ} \mathrm{C}$ for 16 weeks, and $4^{\circ} \mathrm{C}$ for 24 weeks. Single-round viral infection tests were performed using TZM-bl reporter cells and HIV-1 (A) pseudotyped HIV-1 CRF01_AE (CNE55), (B) pseudotyped HIV-1 B (X2278_C2_B6), (C) pseudotyped HIV-1 C (HIV_25710-2.43), and (D) pseudotyped HIV-1 G (X1632_S2_B10). The experiments were performed with an initial concentration of 2P23 peptide at $297 \mathrm{nM}$. These assays were performed in triplicate and repeated three times. Percent inhibition of the $2 \mathrm{P} 23$ gel at $4^{\circ} \mathrm{C}, 25^{\circ} \mathrm{C}, 40^{\circ} \mathrm{C}$, and $60^{\circ} \mathrm{C}$ and $\mathrm{IC}_{50}$ values were calculated as described in the text. Data are expressed as means \pm standard deviations (SD).

of the RL and CVL samples was the same, and the number of highquality reads was similar, suggesting that the irrigation sampling technique effectively restored and amplified bacterial DNA. We obtained 937 million high-quality reads from RL samples and 958 million bacterial reads from CVL samples. Silva 132 was used as a reference database to classify high-quality reads (52). Before investigating whether the immune response after 2P23 gel rectovaginal application correlates with changes in the mucosal microbiome profile, we evaluated the bacterial composition similarities and differences in the rectal and vaginal compartments at baseline (Day 0 of $2 \mathrm{P} 23$ gel rectovaginal application). Figure 8 shows the composition of the microbiota clustered by similarity in the relative abundance of organisms. At the phylum level, the bacterial communities in the rectum and vagina were composed of Firmicutes, Bacteroidetes, Tenericutes, Actinobacteria, Verrucomicrobia, and Proteobacteria (Figure 8A). An assessment of microbial composition at the genus level revealed that the rectal and vaginal microbiota are composed of similar phylotypes (Figure 8B).
We next evaluated changes in the composition of the microbiota in rectal and vaginal samples in response to $2 \mathrm{P} 23$ gel rectovaginal application by bacterial $16 \mathrm{~S}$ rRNA sequencing. Due to the rectovaginal application of the $2 \mathrm{P} 23$ gel, no significant change in Shannon alpha diversity of the rectal or vaginal microbiota was observed (Figure 9A). Comparison of microbial communities at the phylum level showed no significant differences between 2P23gel rectovaginal-applied samples (Figure 9B). Weighted PCoA analysis showed slight differences among animals in most sample clusters and rectal and vaginal microbiomes (Figure 9C). We detected noticeable variation in the relative abundance of Rhizobiales, which belongs to Proteobacteria, and Lactobacillales, which belongs to Firmicutes, in the 2P23 gel high-dose and gel groups (Figure 9D). Overall, the data demonstrated that the rectal and vaginal microbiome is highly polymicrobial and remains largely stable during the course of HIV membrane fusion inhibitor 2P23 microbicide rectovaginal application. Rabbits are relevant models for studying pathogenesis and verifying strategies to prevent the spread of infection. Our study provides a detailed 
A

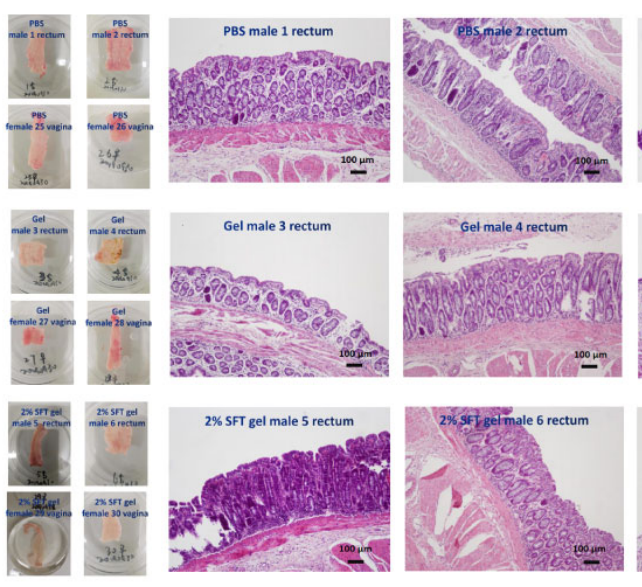

B

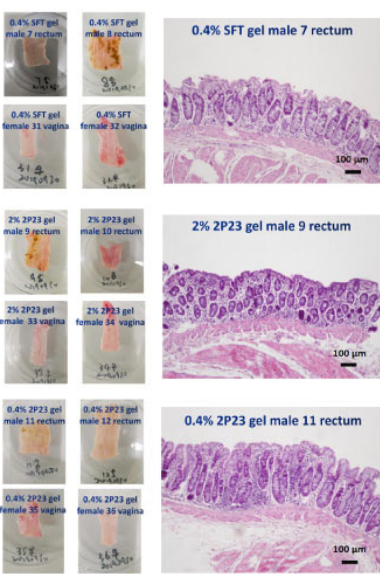

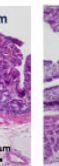

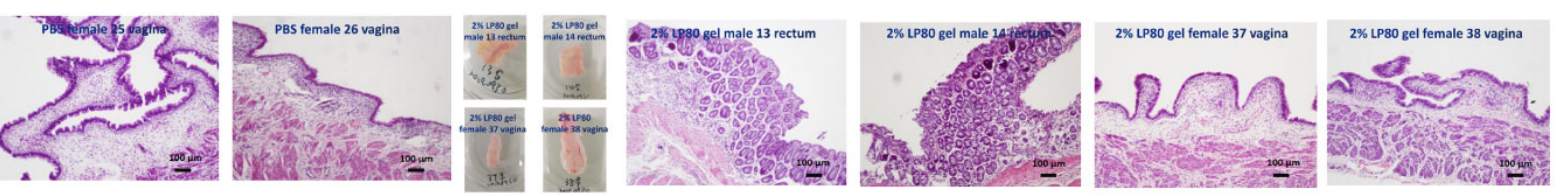
Gel female 27 vagina
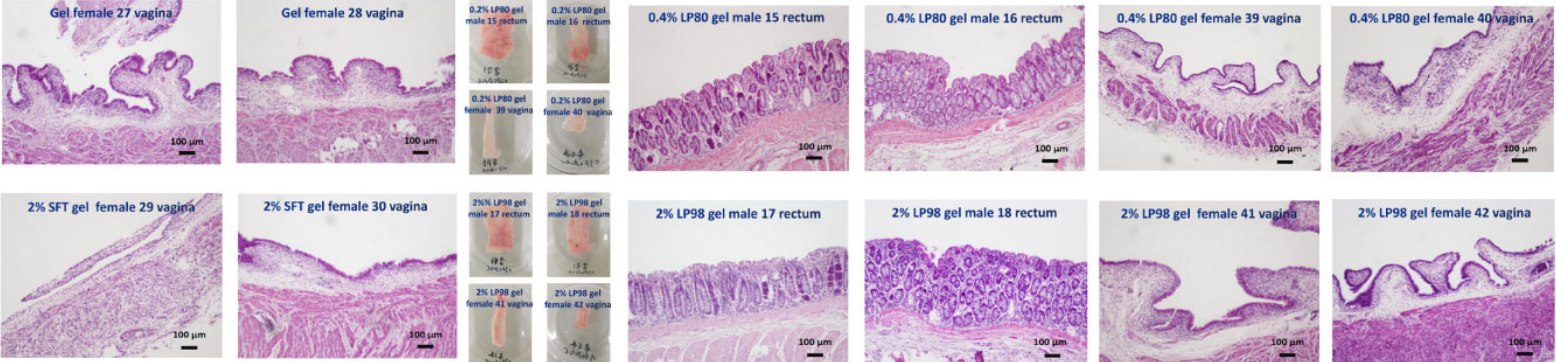

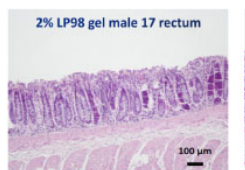

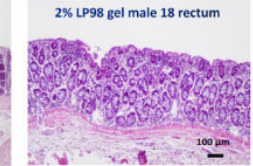

D
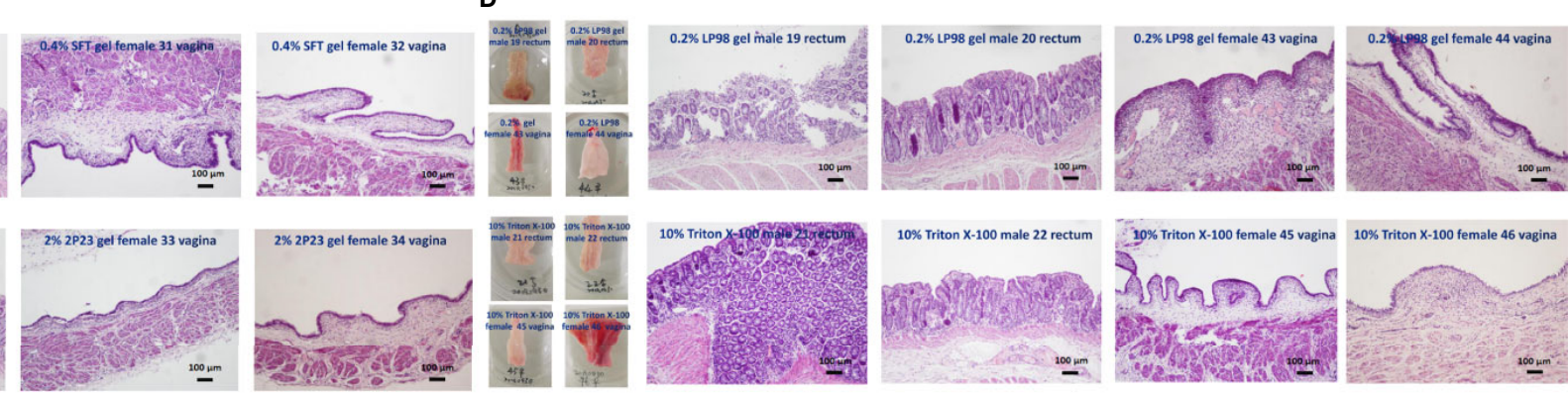

5 ins

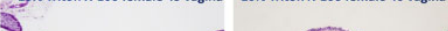

औดก

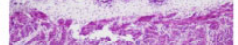

mons res

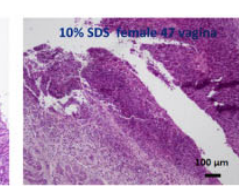
$\stackrel{1000 \mathrm{~mm}}{=}$
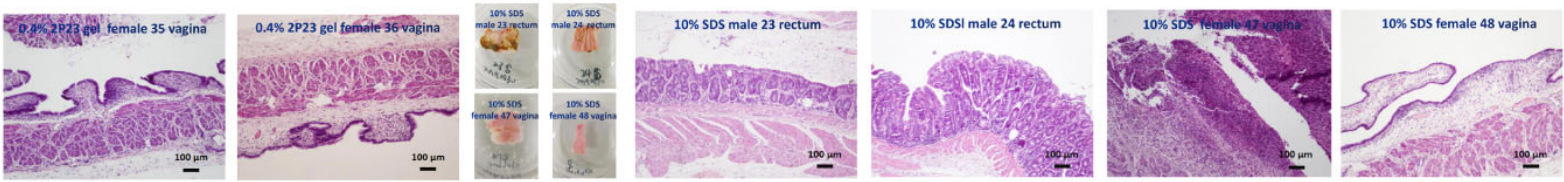

FIGURE 7 | Histopathological analysis of vaginal or rectal epithelium in NZW rabbits of different groups after rectovaginal application of fusion inhibitor microbicides for 14 consecutive days. (A) PBS male rectum 1 , 2; PBS female vagina 25, 26; gel male rectum 3, 4; gel female vagina 27, 28; 2\% SFT gel male rectum 5, 6; 2\% SFT gel female vagina 29, 30. (B) $0.4 \%$ SFT gel male rectum 7, 8; 0.4\% SFT gel female vagina 31, 32; $2 \% 2 \mathrm{P} 23$ gel male rectum 9, 10; 2\% 2P23 gel female vagina 33, 34; 0.4\% 2P23 gel male rectum 11, 12; 0.4\% 2P23 gel female vagina 35,36 . (C) 2\% LP80 gel male rectum 13, 14; 2\% LP80 gel female vagina 37, 38; $0.2 \%$ LP80 gel male rectum 15, 16; 0.2\% LP80 gel female vagina 39, 40; 2\% LP98 gel male rectum 17, 18; 2\% LP98 gel female vagina 41,42 . (D) $0.2 \%$ LP98 gel male rectum 19, 20; 0.2\% LP98 gel female vagina 43, 44; $10 \%$ Triton X-100 male rectum 21, 22; $10 \%$ Triton X-100 female vagina 45, 46; $10 \%$ SDS male rectum 23, 24; $10 \%$ SDS female vagina $47,48$. 


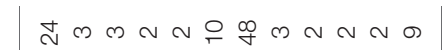
.

irrmortanom

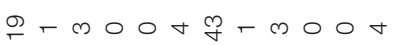

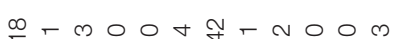

ㄷNOOMF-MOOJ

or nOOMR nOOM

느 - NOOMO $r$ NOOM

J $-N O O M \infty$

m-NOOM M - NOOM

N-mOOナO NOOM

F-mOO

은 n m m n m

a m - O O M - NOOM

m-nOOMNTNOM

n nOOM

or NOOMO - NOOM

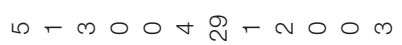

tr nOOM $\stackrel{\infty}{N}-m 00$ \%

m-nOOnN-mOO

n-moor d r moof

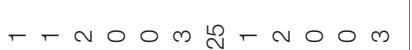

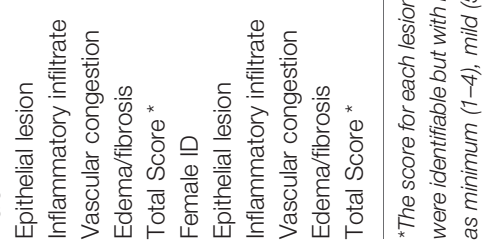

characterization of the rectal and vaginal microbiota of male and female NZW rabbits and opens up new prospects for establishing this animal model. Overall, our data suggest that the safety and ability of 2P23 gels to inhibit HIV infection is independent of rectal and vaginal microbiome differences.

\section{DISCUSSION}

The main findings of this study include the following: (1) the inhibitory effect of 2P23 gel on HIV infection was stable and effective against a broad spectrum of HIV strains, as evidenced by $\mathrm{IC}_{50}$ values ranging from 0.5908 to $2.084 \mathrm{nM}$ in vitro; (2) the potency of anti-HIV infection of 2P23 gel was stable when kept at different temperatures, different $\mathrm{pH}$ values, and different $\mathrm{H}_{2} \mathrm{O}_{2}$ concentrations; (3) 2P23 gel did not induce cell death in PBMCs or immune cells in vitro; and (4) when administered to rabbits, 2P23 gel did not influence physical rectal or vaginal bacterial expansion. Moreover, it induced neither morphological changes nor inflammatory cytokine production in the rectal or vaginal mucosa.

Due to the deleterious destruction of the immune defense system by HIV infection, patients experience a lifelong threat for immunodeficiency-related diseases. If better HIV prevention is attained, a lower incidence of HIV infection is achieved. To date, there are three main strategies for HIV prevention: lifestyle modification, condom use, and microbicides. Given the sustained high rate of HIV infection, a gap remains for education, improved compliance, and recognition of condom usage.

Microbicides circumvent viral infection of targeted cells and therefore hold promise for anti-HIV infection. However, the therapeutic effect of topical PrEP application is dependent on the $\mathrm{ARV}$ regimen. At present, the most promising microbicides are nucleotide reverse transcriptase inhibitors, such as tenofovir. By inhibiting RNA transcription, tenofovir prohibits viral replication, such as hepatitis and HIV infection, in host cells. In a randomized, placebo-controlled trial, 12,320 women with no HIV infection were assigned to oral administration of tenofovir disoproxil fumarate (TDF), tenofovir-emtricitabine (TDF-FTC), or $1 \%$ tenofovir (TFV) vaginal gel and followed up for 12-36 months. By intention-to-treat analysis, the incidence of HIV infection was comparable among all groups $(53,54)$. Likewise, resistance to tenofovir is commonly observed in low- and middle-income countries $(55,56)$. These data suggest that new drugs are needed for HIV prevention.

Previously, we reported a synthetic HIV membrane fusion inhibitor peptide called $2 \mathrm{P} 23$ that has strong activity against HIV-1, HIV-2, and SIV (23). In this study, we further evaluated its physical and biological as well as its toxic effects in vitro and in vivo. When formulated into a gel, 2P23 was stably released, maintained, and blocked HIV infection in vitro, independent of temperature $\left(25^{\circ} \mathrm{C}-60^{\circ} \mathrm{C}\right), \mathrm{pH}(4.0-8.0)$, and $\mathrm{H}_{2} \mathrm{O}_{2}$ concentration. We developed a $2 \mathrm{P} 23$ gel dosage form and examined its physical and chemical properties to meet the requirements of rectal and vaginal administration environments 
TABLE 5 | Inflammatory cytokines in the rectum and vagina after 14 consecutive days of rectovaginal application of fusion inhibitor microbicides in male and female NZW rabbits.

\begin{tabular}{|c|c|c|c|c|c|c|c|c|c|c|c|c|}
\hline Group & PBS & Gel & $2 \%$ SFT gel & $0.4 \%$ SFT gel & $2 \%$ 2P23-gel & $0.4 \% 2 \mathrm{P} 23-\mathrm{gel}$ & $2 \%$ LP80 gel & $0.2 \%$ LP80 gel & 2\% LP98 gel & $0.2 \%$ LP98 gel & $10 \%$ Triton X-100 & $10 \%$ SDS \\
\hline \multicolumn{13}{|l|}{ Male } \\
\hline IL-4 (pg/ml) & 8.495 & 6.260 & 6.445 & 22.932 & 6.819 & 5.235 & 12.283 & 6.290 & 12.438 & 8.805 & 1.354 & 4.707 \\
\hline $\mathrm{IL}-5(\mathrm{pg} / \mathrm{ml})$ & 4.926 & 3.618 & 3.727 & 13.374 & 3.945 & 3.019 & 7.142 & 3.636 & 7.233 & 5.108 & 0.748 & 2.710 \\
\hline IL-6 (pg/ml) & 13.547 & 41.251 & 22.197 & 5.025 & 34.114 & 22.852 & 29.582 & 17.326 & 34.724 & 141.775 & 8.398 & 20.300 \\
\hline IL-8 (pg/ml) & 16.489 & 15.207 & 16.864 & 40.329 & 15.426 & 18.366 & 28.503 & 14.674 & 28.909 & 11.858 & 9.075 & 11.953 \\
\hline IL-10 (pg/ml) & 46.516 & 22.575 & 54.875 & 28.816 & 32.740 & 30.533 & 64.171 & 32.449 & 67.114 & 27.322 & 23.243 & 28.215 \\
\hline |L-17 (pg/ml) & 27.447 & 28.783 & 74.516 & 52.028 & 42.427 & 54.772 & 64.625 & 41.380 & 56.865 & 19.253 & 51.379 & 34.919 \\
\hline IFN- $\gamma(\mathrm{pg} / \mathrm{ml})$ & 92.078 & 29.989 & 208.731 & 55.217 & 36.477 & 56.667 & 138.394 & 213.390 & 168.524 & 74.476 & 69.886 & 33.475 \\
\hline MCP1 (pg/ml) & 316.515 & 290.692 & 458.542 & 518.796 & 341.477 & 312.211 & 359.553 & 298.438 & 392.262 & 265.729 & 291.552 & 302.742 \\
\hline IL1a (pg/ml) & 18.121 & 16.398 & 16.178 & 21.786 & 17.181 & 14.425 & 22.976 & 17.964 & 18.497 & 14.894 & 9.538 & 13.234 \\
\hline IL1RA (pg/ml) & 73.422 & 29.354 & 47.695 & 16.805 & 47.783 & 25.346 & 49.200 & 52.052 & 46.470 & 47.170 & 22.021 & 42.672 \\
\hline E-SELE (pg/ml) & 420.948 & 844.272 & 1,689.902 & 719.662 & 647.309 & $1,502.838$ & $1,475.119$ & 700.284 & $1,029.177$ & $1,565.472$ & 361.133 & 810.675 \\
\hline ICAM1 (pg/ml) & 5.415 & 8.572 & 7.295 & 3.576 & 9.659 & 7.947 & 7.082 & 19.329 & 7.302 & 18.154 & 8.012 & 7.298 \\
\hline VEGFA (pg/ml) & 82.420 & 10.661 & 70.077 & 14.887 & 7.144 & 10.931 & 45.728 & 54.893 & 34.941 & 14.955 & 20.231 & 7.516 \\
\hline PDGFA (pg/ml) & 29.784 & 18.279 & 67.158 & 18.247 & 12.752 & 14.423 & 59.220 & 54.271 & 82.101 & 22.135 & 24.482 & 10.277 \\
\hline \multicolumn{13}{|l|}{ Female } \\
\hline IL-4 (pg/ml) & 5.297 & 5.856 & 13.059 & 7.905 & 7.098 & 4.024 & 14.953 & 6.290 & 4.148 & 3.837 & 5.577 & 13.463 \\
\hline IL-5 (pg/ml) & 3.055 & 3.382 & 7.597 & 4.581 & 4.109 & 2.310 & 8.705 & 3.636 & 2.383 & 2.201 & 3.219 & 7.833 \\
\hline IL-6 (pg/ml) & 13.510 & 12.290 & 29.680 & 8.894 & 5.229 & 2.677 & 7.780 & 9.308 & 10.031 & 3.278 & 26.947 & 5.869 \\
\hline IL-8 (pg/ml) & 29.035 & 27.346 & 33.196 & 34.134 & 18.304 & 20.650 & 26.375 & 16.051 & 22.840 & 69.174 & 22.496 & 108.345 \\
\hline IL-10 (pg/ml) & 61.898 & 63.124 & 54.006 & 49.592 & 76.945 & 70.815 & 34.879 & 53.761 & 60.760 & 79.017 & 20.613 & 121.529 \\
\hline IL-17 (pg/ml) & 51.703 & 53.761 & 48.274 & 64.950 & 87.222 & 101.299 & 73.288 & 60.871 & 82.312 & 54.843 & 80.039 & 150.895 \\
\hline IFN- $\gamma(\mathrm{pg} / \mathrm{ml})$ & 267.266 & 210.009 & 179.637 & 282.037 & 210.147 & 160.310 & 182.122 & 163.071 & 194.892 & 339.087 & 199.793 & 450.771 \\
\hline MCP1 (pg/ml) & 166.741 & 402.592 & 327.705 & 425.832 & 188.26 & 253.678 & 398.288 & 177.931 & 130.588 & 407.756 & 486.947 & 289.831 \\
\hline IL1a (pg/ml) & 13.986 & 14.801 & 15.928 & 23.133 & 14.268 & 12.764 & 23.853 & 16.366 & 10.446 & 14.643 & 10.227 & 26.955 \\
\hline IL1RA (pg/ml) & 52.771 & 50.180 & 121.304 & 37.387 & 51.335 & 53.611 & 56.183 & 52.718 & 82.872 & 77.166 & 51.388 & 156.026 \\
\hline E-SELE (pg/ml) & $1,694.582$ & $1,813.372$ & $1,258.297$ & $1,631.046$ & $1,879.006$ & $2,232.737$ & $1,933.241$ & $1,750.316$ & $1,510.216$ & $2,038.053$ & $1,991.377$ & $1,421.484$ \\
\hline ICAM1 (pg/ml) & 9.161 & 13.541 & 9.722 & 41.344 & 9.672 & 7.898 & 10.505 & 7.948 & 6.441 & 9.798 & 35.134 & 10.787 \\
\hline VEGFA (pg/ml) & 62.401 & 81.947 & 46.100 & 65.105 & 61.116 & 45.560 & 62.062 & 38.762 & 41.806 & 88.541 & 58.647 & 88.609 \\
\hline PDGFA (pg/ml) & 125.903 & 85.315 & 58.031 & 64.619 & 65.776 & 65.198 & 69.954 & 34.315 & 58.352 & 159.292 & 194.449 & 99.037 \\
\hline
\end{tabular}




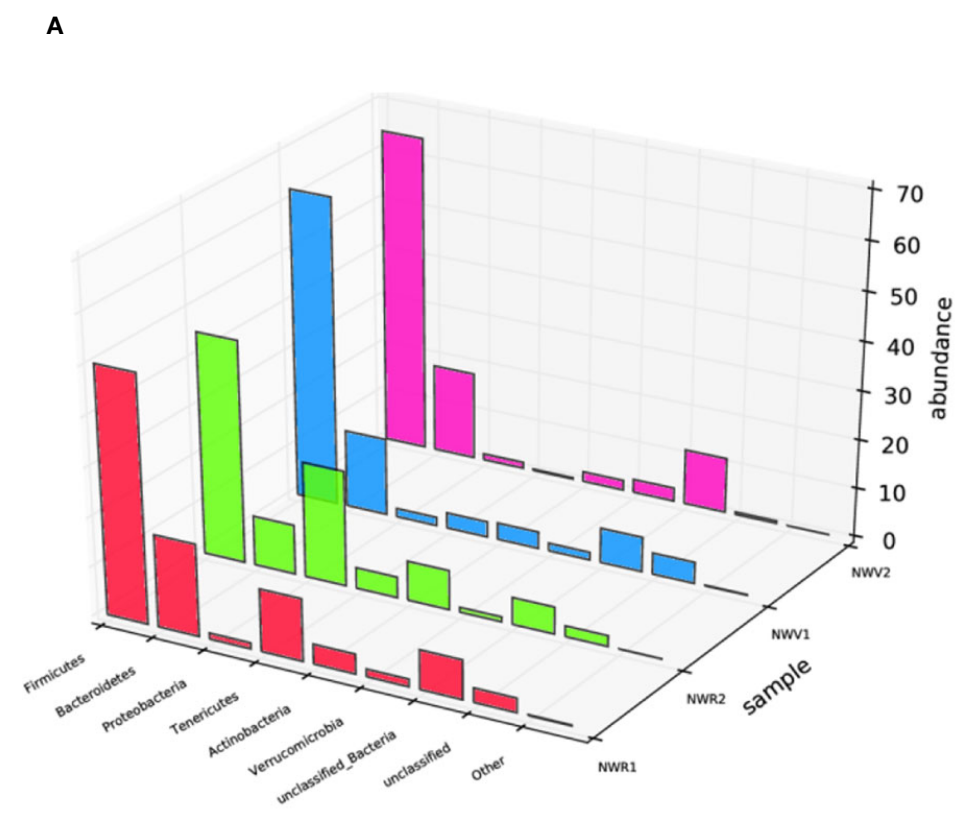

B

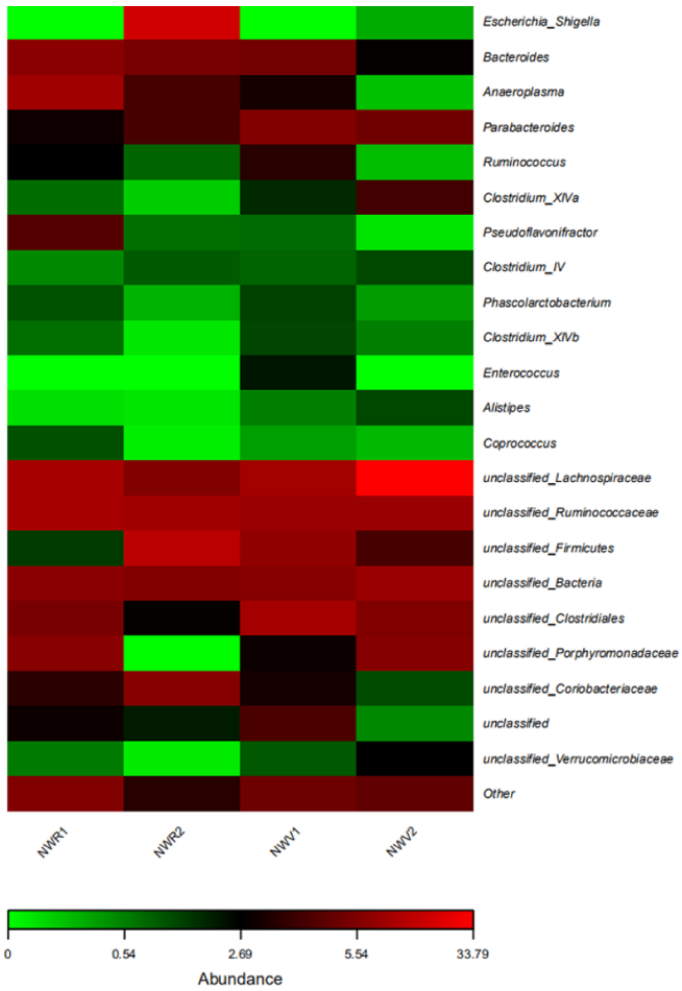

FIGURE 8 | Diversity of microbial community composition across the rectum and vagina. (A) The composition of the microbiota was visualized by 3D bar plots. The horizontal axis represents the bacterial colonies. The vertical axis represents the relative abundance ratio. The $z$-axis represents the sample. (B) Heat map showing the top 23 similarly abundant genera in the rectum versus vagina. Each column represents data from a single animal.

and reduce irritation (57-60). HEC was added to the preparation as a gel matrix so that the preparation had a suitable viscosity and could be retained in the rectum and vagina. After 14 days of continuous rectovaginal application of the 2P23 gel, no 2P23 gelrelated changes in physical signs or body weight were observed in rabbits. Histopathological examination found no irritation of the $2 \mathrm{P} 23$ gel to the rectal or vaginal mucosa, indicating that the product has good safety.

Notably, 2P23 had no effect on physical bacterial expansion in the rectum or vagina in vitro or in vivo, which is crucial for biological defense and function in the body. This is important because rectovaginal application of microbicides should protect the normal rectal and vaginal microbiota, particularly Lactobacillus, Bifidobacterium, Enterobacter, and Enterococcus, which are essential for maintaining a balance of a healthy rectal and vaginal bacterial ecosystem. Loss of rectal and vaginal mucosal integrity and abnormal rectal and vaginal microbiota, e.g., the abundance of $\gamma$-Proteobacteria, the absence of Lachnospiraceae and Ruminococcaceae, and the reduction of alpha diversity are thought to be mechanisms that lead to chronic inflammation and increased morbidity and mortality during antiretroviral therapy for HIV disease (61-63). The vaginal microflora dominated by Lactobacillus may be enhanced, and inflammatory cytokines may attenuate the protective effect of vaginal TFV gel in healthy HIV-negative women (64-66).

This is the first study to evaluate the rectal and vaginal use of the $2 \mathrm{P} 23$ gel. The safety and stability of the $2 \mathrm{P} 23$ gel indicate that the HIV membrane fusion inhibitor 2P23 peptide is an optimal microbicide for HIV prevention.

\section{CONCLUSIONS}

In conclusion, this multiplatform study, which combines cytokine and microbiome monitoring techniques, provides comprehensive information on the rectal and vaginal mucosal environment at a systematic level, providing an additional tool for preclinical microbicide safety evaluation. In general, the $2 \mathrm{P} 23$ microbicide gel did not have any significant effect on mucosal cytokines and had only a small effect on the microbiome, indicating its tolerability and suitability as a candidate microbicide. This study highlights the use of 2P23 gel as a suitable candidate for PrEP, which may offer the potential for better adoption and effective HIV prevention by men and women in end users. The 2P23 gel did not cause cellular or bacterial toxicity, nor did it alter the microbiome of the rectum or vagina. The versatility of gel formulations offers the potential to create products that protect men and women from HIV infection and enhance mucosal health. 
A

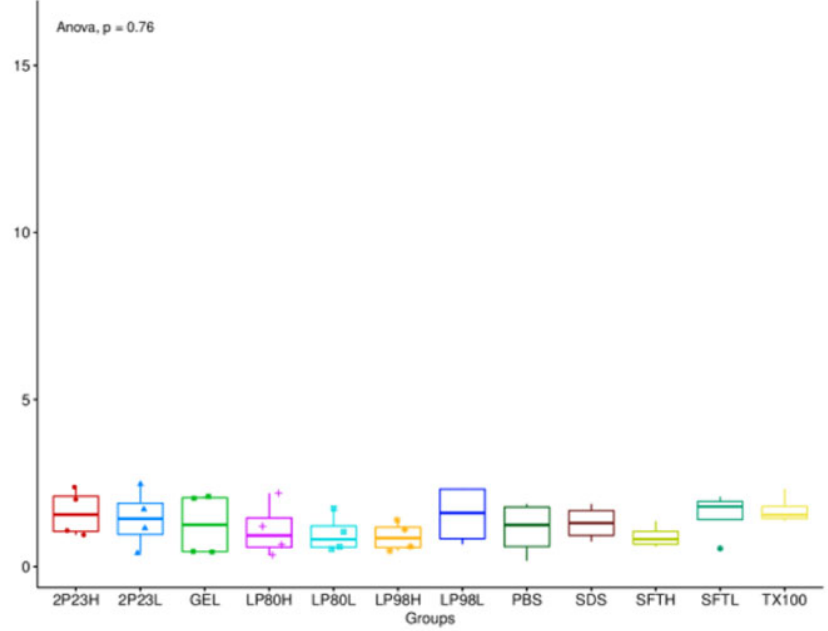

c

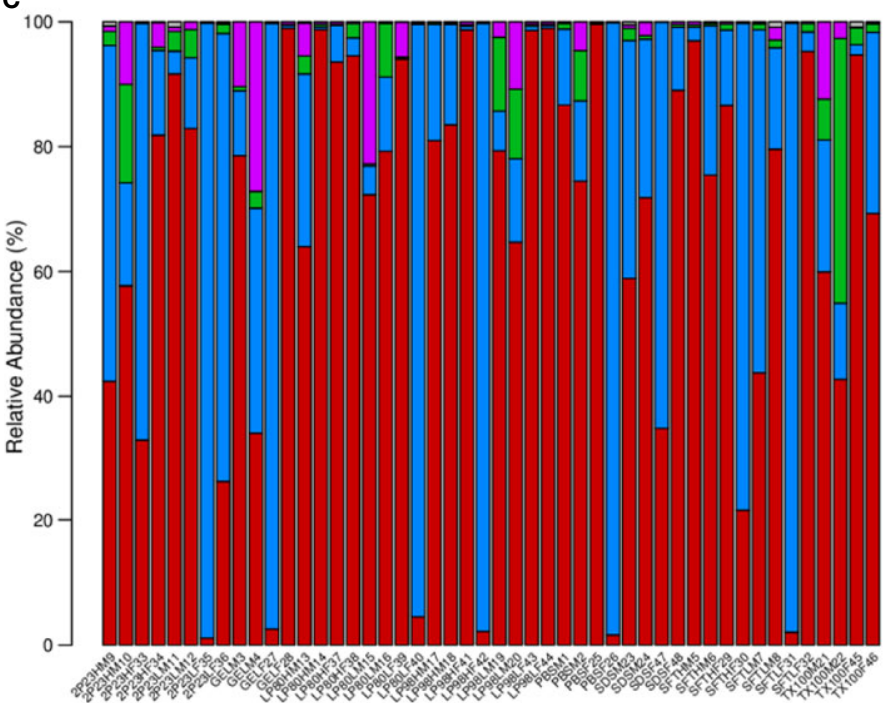

B

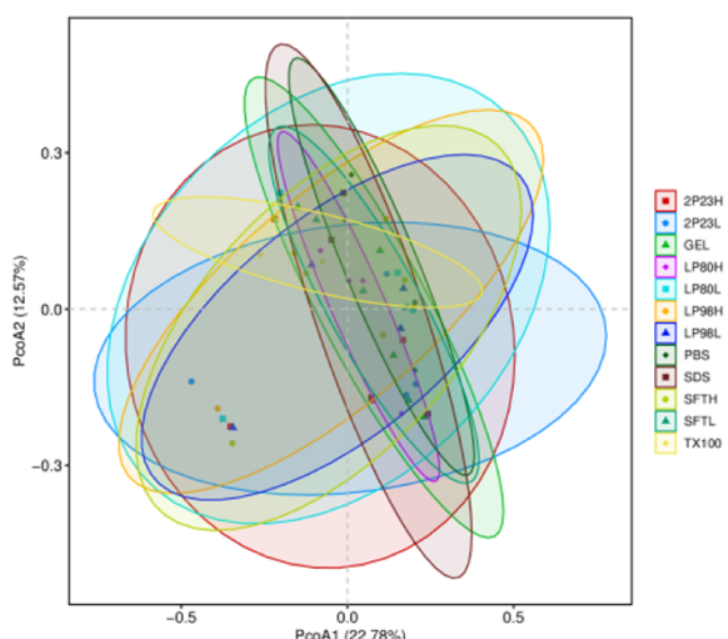

D

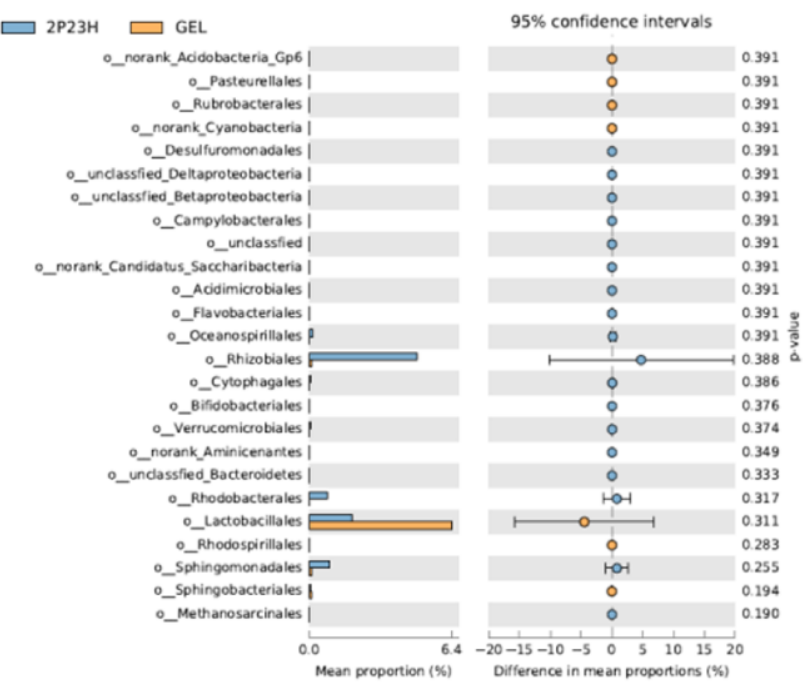

FIGURE 9 | Microbial changes following 2P23 gel administration. (A) Rectal and vaginal microbiota comparison following 2P23 gel administration was analyzed using shannon_alpha diversity test. (B) 16S rRNA sequence data from paired rectal and vaginal samples showed unique clustering evident from a principal coordinate analysis (PCoA) plot based on unweighted UniFrac distances between bacterial communities across each mucosal site at day 14. (C) Histogram of the relative abundance of taxonomic classification at the phylum level. The horizontal axis is the serial number of each sample, and the vertical axis is the relative abundance ratio of species. Colors correspond to species names at this taxonomic level, and different color block widths represent the relative abundance ratio of different species. (D) Diagram of difference analytic results at the genus level list only the 25 with the lowest $p$-values. The figure on the left shows the abundance ratio of different species in the two groups of samples; the middle shows the $95 \%$ confidence interval, the proportion of differences in species abundances; the rightmost value is a $p$-value, where a $p$-value $<0.05$ indicates a significant difference. 


\section{DATA AVAILABILITY STATEMENT}

The datasets presented in this study can be found in online repositories. The names of the repository/repositories and accession number(s) can be found below: NCBI SRA; PRJNA726948.

\section{ETHICS STATEMENT}

All animal experiments were performed according to the guidelines and protocols approved by the Ethics Committee for Animal Experimentation of National Institutes for Food and Drug Control (NIFDC; Beijing, China). All animal experiments were reviewed and approved by the Institutional Animal Care and Use Committee (IACUC) of NIFDC (approved on 2 August 2019; protocol No. 2019 (B) 010). To ensure personnel safety and animal welfare, the study of animals were conducted in strict accordance with the recommendations for conducting experiments were in accord with the highest scientific,

\section{REFERENCES}

1. Communications and Global Advocacy. UNAIDS. FACT SHEET-WORD AIDS DAY 2020. GLOBAL HIV STATISTICS (2020). Available at: https:// www.unaids.org/sites/default/files/media_asset/UNAIDS_FactSheet_en. pdf2020.

2. Claborn KR, Meier E, Miller MB, Leffingwell TR. A Systematic Review of Treatment Fatigue Among HIV-Infected Patients Prescribed Antiretroviral Therapy. Psychol Health Med (2015) 20(3):255-65. doi: 10.1080/ 13548506.2014.945601

3. Boretzki J, Wolf E, Wiese C, Noe S, Balogh A, Meurer A, et al. Highly Specific Reasons for Nonadherence to Antiretroviral Therapy: Results From the German Adherence Study. Patient Prefer Adherence (2017) 11:1897-906. doi: 10.2147/PPA.S141762

4. Shaw GM, Hunter E. HIV Transmission. Cold Spring Harb Perspect Med (2012) 2(11):a006965. doi: 10.1101/cshperspect.a006965

5. Stannah J, Silhol R, Elmes J, Owen B, Shacklett BL, Anton P, et al. Increases in HIV Incidence Following Receptive Anal Intercourse Among Women: A Systematic Review and Meta-Analysis. AIDS Behav (2020) 24(3):667-81. doi: 10.1007/s10461-019-02651-0

6. WHO. Focus on Key Populations in National HIV Strategic Plans in the African Region. Congo: Regional Office for Africa (2018).

7. Stein ZA. HIV Prevention: The Need for Methods Women can Use. Am J Public Health (1990) 80(4):460-62. doi: 10.2105/ajph.80.4.460

8. Foss AM, Vickerman PT, Heise L, Watts $\mathrm{CH}$. Shifts in Condom Use Following Microbicide Introduction: Should We be Concerned? AIDS (2003) 17(8):1227-37. doi: 10.1097/00002030-200305230-00015

9. Remis RS, Alary M, Liu J, Kaul R, Palmer RW. HIV Transmission Among Men Who Have Sex With Men Due to Condom Failure. PloS One (2014) 9: e107540. doi: 10.1371/journal.pone.0107540

10. Turpin JA. Considerations and Development of Topical Microbicides to Inhibit the Sexual Transmission of HIV. Expert Opin Investig Drugs (2002) 11(8):1077-97. doi: 10.1517/13543784.11.8.1077

11. Baeten J, Celum C. Systemic and Topical Drugs for the Prevention of HIV Infection: Antiretroviral Pre-Exposure Prophylaxis. Annu Rev Med (2013) 64:219-32. doi: 10.1146/annurev-med-050911-163701

12. Rohan LC, Devlin B, Yang H. Microbicide Dosage Forms. Curr Top Microbiol Immunol (2014) 383:27-54. doi: 10.1007/82_2013_357

13. Weir SS, Roddy RE, Zekeng L, Feldblum PJ. Nonoxynol-9 Use, Genital Ulcers, and HIV Infection in a Cohort of Sex Workers. Genitourin Med (1995) 71:7881. doi: $10.1136 /$ sti.71.2.78 humane, and ethical principles as stated in the Guide for the Care and Use of Laboratory Animals. Written informed consent was obtained from the owners for the participation of their animals in this study.

\section{AUTHOR CONTRIBUTIONS}

ZG and $\mathrm{YH}$ conceived the study and designed the experiments. $\mathrm{ZG}, \mathrm{RF}, \mathrm{XL}$, and JW performed the experiments. ZG and $\mathrm{YH}$ wrote the article. All authors contributed to the article and approved the submitted version.

\section{FUNDING}

This study was supported by the grant from the CAMS Innovation Fund for Medical Sciences (2017-I2M-1014). The funders had no role in study design, data collection and analysis, decision to publish, or preparation of the manuscript.

14. Van Damme L, Govinden R, Mirembe FM, Guédou F, Solomon S, Becker ML, et al. Lack of Effectiveness of Cellulose Sulfate Gel for the Prevention of Vaginal HIV Transmission. N Engl J Med (2008) 359(5):463-72. doi: 10.1056/ NEJMoa0707957

15. Thigpen MC, Kebaabetswe PM, Paxton LA, Smith DK, Rose CE, Segolodi TM, et al. Antiretroviral Preexposure Prophylaxis for Heterosexual HIV Transmission in Botswana. N Engl J Med (2012) 367(5):423-34. doi: 10.1056/ NEJMoa1110711

16. Baeten JM, Donnell D, Ndase P, Mugo NR, Campbell JD, Wangisi J, et al. Partners PrEP Study Team. Antiretroviral Prophylaxis for HIV Prevention in Heterosexual Men and Women. N Engl J Med (2012) 367(5):399-410. doi: 10.1056/NEJMoa1108524

17. Abdool Karim Q, Abdool Karim SS, Frohlich JA, Grobler AC, Baxter C, Mansoor LE, et al. Effectiveness and Safety of Tenofovir Gel, an Antiretroviral Microbicide, for the Prevention of HIV Infection in Women. Science (2010) 329(5996):1168-74. doi: 10.1126/science.1193748

18. Ngandu NK, Carlson JM, Chopera DR, Ndabambi N, Abdool Karim Q, Abdool Karim S, et al. Brief Report: Selection of HIV-1 Variants With Higher Transmission Potential by $1 \%$ Tenofovir Gel Microbicide. J. Acquir Immune Defic Syndr (2017) 76(1):43-7. doi: 10.1097/QAI.0000000000001458

19. Nel A, van Niekerk N, Kapiga S, Bekker LG, Gama C, Gill K, et al. Safety and Efficacy of a Dapivirine Vaginal Ring for HIV Prevention in Women. N Engl J Med (2016) 375(22):2133-43. doi: 10.1056/NEJMoa1602046

20. Bártolo I, Diniz AR, Borrego P, Ferreira JP, Bronze MR, Barroso H, et al. Evaluation of the Fusion Inhibitor P3 Peptide as a Potential Microbicide to Prevent HIV Transmission in Women. PloS One (2018) 13(4):e0195744. doi: 10.1371/journal.pone.0195744

21. Cranston RD, Lama JR, Richardson BA, Carballo-Dieguez A, Kunjara Na Ayudhya RP, Liu K, et al. MTN-017: A Rectal Phase 2 Extended Safety and Acceptability Study of Tenofovir Reduced-Glycerin 1\% Gel. Clin Infect Dis (2017) 64:614-20. doi: 10.1093/cid/ciw832

22. Gupta SK, Nutan. Clinical Use of Vaginal or Rectally Applied Microbicides in Patients Suffering From HIV/AIDS. HIV AIDS (Auckl) (2013) 5:295-307. doi: 10.2147/HIV.S39164

23. Xiong S, Borrego P, Ding X, Zhu Y, Martins A, Chong H, et al. A Helical Short-Peptide Fusion Inhibitor With Highly Potent Activity Against Human Immunodeficiency Virus Type 1 (HIV-1), HIV-2, and Simian Immunodeficiency Virus. J Virol (2017) 91(1):e01839-16. doi: 10.1128/ JVI.01839-16

24. Derdeyn CA, Decker JM, Sfakianos JN, Wu X, O'Brien WA, Ratner L, et al. Sensitivity of Human Immunodeficiency Virus Type 1 to the Fusion Inhibitor 
T-20 Is Modulated by Coreceptor Specificity Defined by the V3 Loop of Gp120. J Virol (2000) 74(18):8358-67. doi: 10.1128/jvi.74.18.8358-8367.2000

25. Platt EJ, Wehrly K, Kuhmann SE, Chesebro B, Kabat D. Effects of CCR5 and CD4 Cell Surface Concentrations on Infections by Macrophagetropic Isolates of Human Immunodeficiency Virus Type 1. J Virol (1998) 72(4):2855-64. doi: 10.1128/JVI.72.4.2855-2864.1998

26. Platt EJ, Bilska M, Kozak SL, Kabat D, Montefiori DC. Evidence That Ecotropic Murine Leukemia Virus Contamination in TZM-Bl Cells Does Not Affect the Outcome of Neutralizing Antibody Assays With Human Immunodeficiency Virus Type 1. J Virol (2009) 83(16):8289-92. doi: 10.1128/JVI.00709-09

27. Takeuchi Y, McClure MO, Pizzato M. Identification of Gammaretroviruses Constitutively Released From Cell Lines Used for Human Immunodeficiency Virus Research. J Virol (2008) 82(24):12585-88. doi: 10.1128/JVI.01726-08

28. Chesebro B, Wehrly K. Development of a Sensitive Quantitative Focal Assay for Human Immunodeficiency Virus Infectivity. J Virol (1988) 62(10):377988. doi: 10.1128/JVI.62.10.3779-3788.1988

29. Chesebro B, Buller R, Portis J, Wehrly K. Failure of Human Immunodeficiency Virus Entry and Infection in CD4-Positive Human Brain and Skin Cells. J Virol (1990) 64(1):215-21. doi: 10.1128/JVI.64.1.215-221.1990

30. Reed LJ, Muench H. A Simple Method of Estimating Fifty Percent Endpoints. Am J Hygiene (1938) 27(3):493-7. doi: 10.1093/oxfordjournals.aje.a118408

31. Wei X, Decker JM, Liu H, Zhang Z, Arani RB, Kilby JM, et al. Emergence of Resistant Human Immunodeficiency Virus Type 1 in Patients Receiving Fusion Inhibitor (T-20) Monotherapy. Antimicrob Agents Chemother (2002) 46(6):1896-905. doi: 10.1128/aac.46.6.1896-1905.2002

32. Richardson BA, Kelly C, Ramjee G, Fleming T, Makanani B, Roberts S, et al. HPTN 035 Study Team. Appropriateness of Hydroxyethylcellulose Gel as a Placebo Control in Vaginal Microbicide Trials. J Acquir Immune Defic Syndr (2013) 63(1):120-25. doi: 10.1097/QAI.0b013e31828607c5

33. Schwartz JL, Ballagh SA, Kwok C, Mauck CK, Weiner DH, Rencher WF, et al. Fourteen-Day Safety and Acceptability Study of the Universal Placebo Gel. Contraception (2007) 75(2):136-41. doi: 10.1016/j.contraception.2006.09.003

34. Tien D, Schnaare RL, Kang F, Cohl G, McCormick TJ, Moench TR, et al. In Vitro and In Vivo Characterization of a Potential Universal Placebo Designed for Use in Vaginal Microbicide Clinical Trials. AIDS Res Hum Retroviruses (2005) 21(10):845-53. doi: 10.1089/aid.2005.21.845

35. ISO 10993-5: (Biological Evaluation of Medical Devices-Part 5: Tests for in Vitro Cytotoxicity, https://www.iso.org/standard/36406.html) (2009).

36. Clinical and Laboratory Standards Institute. Performance Standards for Antimicrobial Susceptibility Testing, 29th Informational Supplement. CLSI M100-S29, Clinical and Laboratory Standards Institute (CLSI), 950 West Valley Roadn Suite 2500. Wayne, Pennsylvania 19087, USA (2018).

37. Clinical and Laboratory Standards Institute (CLSI). Methods for Dilution Antimicrobial Susceptibilities Tests for Bacteria That Grow Aerobically; Approved Standard, 11th Edition, CLSI Document M07-A10, Clinical Laboratory and Standards Institute (CLSI), 950 West Valley Roadn Suite 2500. Wayne, Pennsylvania 19087, USA (2018).

38. Al-Mushrif S, Jones BM. A Study of the Prevalence of Hydrogen Peroxide Generating Lactobacilli in Bacterial Vaginosis: The Determination of $\mathrm{H}_{2} \mathrm{O}_{2}$ Concentrations Generated, In Vitro, by Isolated Strains and the Levels Found in Vaginal Secretions of Women With and Without Infection. $J$ Obstet Gynaecol (1998) 18(1):63-7. doi: 10.1080/01443619868325

39. Eckstein P, Jackson MC, Millman N. Comparison of Vaginal Tolerance Tests of Spermicidal Preparations in Rabbits and Monkeys. J Reprod Fertil (1969) 20 (1):85-93. doi: 10.1530/jrf.0.0200085

40. ISO 10993-10: (Biological Evaluation of Medical Devices-Part 10: Tests for Irritation and Skin Sensitization, https://www.iso.org/standard/40884.html) (2010).

41. Klindworth A, Pruesse E, Schweer T, Peplies J, Quast C, Horn M, et al. Evaluation of General 16S Ribosomal RNA Gene PCR Primers for Classical and Next-Generation Sequencing-Based Diversity Studies. Nucleic Acids Res (2013) 41(1):e1. doi: 10.1093/nar/gks808

42. Köchling T, Sanz JL, Gavazza S, Florencio L. Analysis of Microbial Community Structure and Composition in Leachates From a Young Landfill by 454 Pyrosequencing. Appl Microbiol Biotechnol (2015) 99 (13):5657-68. doi: 10.1007/s00253-015-6409-4

43. Kozich JJ, Westcott SL, Baxter NT, Highlander SK, Schloss PD. Development of a Dual-Index Sequencing Strategy and Curation Pipeline for Analyzing
Amplicon Sequence Data on the MiSeq Illumina Sequencing Platform. Appl Environ Microbiol (2013) 79(17):5112-20. doi: 10.1128/AEM.01043-13

44. Edgar RC. UPARSE: Highly Accurate OTU Sequences From Microbial Amplicon Reads. Nat Methods (2013) 10(10):996-98. doi: 10.1038/ nmeth.2604

45. Wang Q, Garrity GM, Tiedje JM, Cole JR. Naive Bayesian Classifier for Rapid Assignment of rRNA Sequences Into the New Bacterial Taxonomy. Appl Environ Microbiol (2007) 73(16):5261-67. doi: 10.1128/AEM.00062-07

46. Cole JR, Wang Q, Fish JA, Chai B, McGarrell DM, Sun Y, et al. Ribosomal Database Project: Data and Tools for High Throughput rRNA Analysis. Nucleic Acids Res (2014) 42(Database issue):D633-42. doi: 10.1093/nar/ gkt1244

47. DeSantis TZ, Hugenholtz P, Larsen N, Rojas M, Brodie EL, Keller K, et al. Greengenes, a Chimera-Checked 16S rRNA Gene Database and Workbench Compatible With ARB. Appl Environ Microbiol (2006) 72(7):50695-072. doi: 10.1128/AEM.03006-05

48. Huerta-Cepas J, Serra F, Bork P. ETE 3: Reconstruction, Analysis, and Visualization of Phylogenomic Data. Mol Biol Evol (2016) 33(6):1635-38. doi: 10.1093/molbev/msw046

49. Kanehisa M, Goto S. KEGG: Kyoto Encyclopedia of Genes and Genomes. Nucleic Acids Res (2000) 28(1):27-30. doi: 10.1093/nar/28.1.27

50. Burgener A, McGowan I, Klatt NR. HIV and Mucosal Barrier Interactions: Consequences for Transmission and Pathogenesis. Curr Opin Immunol (2015) 36:22-30. doi: 10.1016/j.coi.2015.06.004

51. Cheu RK, Gustin AT, Lee C, Schifanella L, Miller CJ, Ha A, et al. Impact of Vaginal Microbiome Communities on HIV Antiretroviral-Based PreExposure Prophylaxis (PrEP) Drug Metabolism. PloS Pathog (2020) 16(12): e1009024. doi: 10.1371/journal.ppat.1009024

52. Quast C, Pruesse E, Yilmaz P, Gerken J, Schweer T, Yarza P, et al. The SILVA Ribosomal RNA Gene Database Project: Improved Data Processing and WebBased Tools. Nucleic Acids Res (2013) 41(Database issue):D590-96. doi: 10.1093/nar/gks1219

53. Marrazzo JM, Ramjee G, Richardson BA, Gomez K, Mgodi N, Nair G, et al. Tenofovir-Based Preexposure Prophylaxis for HIV Infection Among African Women. N Engl J Med (2015) 372(6):509-18. doi: 10.1056/NEJMoa1402269

54. Delany-Moretlwe S, Lombard C, Baron D, Bekker LG, Nkala B, Ahmed K, et al. Tenofovir 1\% Vaginal Gel for Prevention of HIV-1 Infection in Women in South Africa (FACTS-001): A Phase 3, Randomised, Double-Blind, Placebo-Controlled Trial. Lancet Infect Dis (2018) 18(11):1241-50. doi: 10.1016/S1473-3099(18) 30428-6

55. Morris GC, Lacey CJ. Microbicides and HIV Prevention: Lessons From the Past, Looking to the Future. Curr Opin Infect Dis (2010) 23(1):57-63. doi: 10.1097/QCO.0b013e328334de6d

56. The TenoRes Study Group. Global Epidemiology of Drug Resistance After Failure of WHO Recommended First-Line Regimens for Adult HIV-1 Infection: A Multicentre Retrospective Cohort Study. Lancet Infect Dis (2016) 16(5):565-75. doi: 10.1016/S1473-3099(15)00536-8

57. Reagan-Shaw S, Nihal M, Ahmad N. Dose Translation From Animal to Human Studies Revisited. FASEB J (2008) 22(3):659-61. doi: 10.1096/ff.07-9574LSF

58. Kaminsky M, Willigan DA. pH and the Potential Irritancy of Douche Formulations to the Vaginal Mucosa of the Albino Rabbit and Rat. Food Chem Toxicol (1982) 20(2):193-96. doi: 10.1016/s0278-6915(82)80247-0

59. Chvapil M, Chvapil TA, Owen JA, Kantor M, Ulreich JB, Eskelson C. Reaction of Vaginal Tissue of Rabbits to Inserted Sponges Made of Various Materials. J BioMed Mater Res (1979) 13(1):1-13. doi: 10.1002/jbm.820130103

60. Müller P, Raabe G, Hörold J, Juretzek U. Action of Chronic Peracetic Acid (Wofasteril) Administration on the Rabbit Oral Mucosa, Vaginal Mucosa and Skin. Exp Pathol (1988) 34(4):223-28. doi: 10.1016/s0232-1513(88)80154-3

61. Petrova MI, Lievens E, Malik S, Imholz N, Lebeer S. Lactobacillus Species as Biomarkers and Agents That can Promote Various Aspects of Vaginal Health. Front Physiol (2015) 6:2015.00081. doi: 10.3389/fphys.2015.00081

62. Noguera-Julian M, Rocafort $M$, Guillén $Y$, Rivera J, Casadellà M, Nowak P, et al. Gut Microbiota Linked to Sexual Preference and HIV Infection. EBioMedicine (2016) 5:135-46. doi: 10.1016/j.ebiom.2016.01.032

63. Vujkovic-Cvijin I, Sortino O, Verheij E, Sklar J, Wit FW, Kootstra NA, et al. HIV-Associated Gut Dysbiosis Is Independent of Sexual Practice and Correlates With Noncommunicable Diseases. Nat Commun (2020) 11 (1):2448. doi: 10.1038/s41467-020-16222-8 
64. Klatt NR, Cheu R, Birse K, Zevin AS, Perner M, Noël-Romas L, et al. Vaginal Bacteria Modify HIV Tenofovir Microbicide Efficacy in African Women. Science (2017) 356(6341):938-45. doi: 10.1126/science.aai9383

65. Liebenberg LJ, Masson L, Arnold KB, Mckinnon LR, Werner L, Proctor E, et al. Genital-Systemic Chemokine Gradients and the Risk of HIV Acquisition in Women. J Acquir Immune Defic Syndr (2017) 74(3):318-25. doi: 10.1097/ QAI.0000000000001218

66. Velloza J, Heffron R. The Vaginal Microbiome and its Potential to Impact Efficacy of HIV Pre-Exposure Prophylaxis for Women. Curr HIV/AIDS Rep (2017) 14(5):153-60. doi: 10.1007/s11904-017-0362-Z

Conflict of Interest: The authors declare that the research was conducted in the absence of any commercial or financial relationships that could be construed as a potential conflict of interest.
Publisher's Note: All claims expressed in this article are solely those of the authors and do not necessarily represent those of their affiliated organizations, or those of the publisher, the editors and the reviewers. Any product that may be evaluated in this article, or claim that may be made by its manufacturer, is not guaranteed or endorsed by the publisher.

Copyright (C) 2021 Gao, Fu, Li, Wang and He. This is an open-access article distributed under the terms of the Creative Commons Attribution License (CC BY). The use, distribution or reproduction in other forums is permitted, provided the original author(s) and the copyright owner(s) are credited and that the original publication in this journal is cited, in accordance with accepted academic practice. No use, distribution or reproduction is permitted which does not comply with these terms. 